\title{
Recombinant antibodies and their use for food immunoanalysis
}

\author{
Riikka Peltomaa $^{1,2}$ (1) $\cdot$ Rodrigo Barderas $^{3}$ (i) $\cdot$ Elena Benito-Peña ${ }^{4} \cdot$ María C. Moreno-Bondi $^{4}$ (i)
}

Received: 15 June 2021 /Revised: 4 August 2021 / Accepted: 12 August 2021 / Published online: 21 August 2021

(C) Springer-Verlag GmbH Germany, part of Springer Nature 2021

\begin{abstract}
Antibodies are widely employed as biorecognition elements for the detection of a plethora of compounds including food and environmental contaminants, biomarkers, or illicit drugs. They are also applied in therapeutics for the treatment of several disorders. Recent recommendations from the EU on animal protection and the replacement of animal-derived antibodies by non-animal-derived ones have raised a great controversy in the scientific community. The application of recombinant antibodies is expected to achieve a high growth rate in the years to come thanks to their versatility and beneficial characteristics in comparison to monoclonal and polyclonal antibodies, such as stability in harsh conditions, small size, relatively low production costs, and batch-to-batch reproducibility. This review describes the characteristics, advantages, and disadvantages of recombinant antibodies including antigen-binding fragments $(\mathrm{Fab})$, single-chain fragment variable (scFv), and single-domain antibodies $\left(\mathrm{V}_{\mathrm{HH}}\right)$ and their application in food analysis with especial emphasis on the analysis of biotoxins, antibiotics, pesticides, and foodborne pathogens. Although the wide application of recombinant antibodies has been hampered by a number of challenges, this review demonstrates their potential for the sensitive, selective, and rapid detection of food contaminants.
\end{abstract}

Keywords Recombinant antibody $\cdot$ Antibody fragment $\cdot$ Food analysis $\cdot$ Biosensing $\cdot$ Immunoassay

\section{Introduction}

Antibodies play a pivotal role in biomedical research, diagnostics, therapeutics, and virtually every branch of biotechnology. These fascinating proteins are characterized by their exceptional ability to identify and bind to specific targets of interest, even in a complex environment. The exquisite specificity of antibodies has also paved the way for their ubiquitous use as biorecognition elements in biosensing applications. Antibody-based sensors

Published in the topical collection celebrating ABCS 20th Anniversary.

Elena Benito-Peña

elenabp@ucm.es

María C. Moreno-Bondi

mcmbondi@ucm.es

1 Department of Life Sciences, University of Turku, 20014 Turku, Finland

2 Turku Collegium for Science and Medicine, University of Turku, 20014 Turku, Finland

3 Chronic Disease Programme, UFIEC, Instituto de Salud Carlos III, 28220 Madrid, Spain

4 Department of Analytical Chemistry, Universidad Complutense de Madrid, 28040 Madrid, Spain and assays - immunosensors and immunoassays - have revolutionized the analysis of a plethora of analytes, including biomarkers as well as food and environmental contaminants. Consequently, there is a continuous demand for antibodies or antibody mimics in research and development.

Formerly, immunoassays were mainly based on polyclonal antibodies (pAb) from the sera of immunized mice or rabbits, or monoclonal antibodies (mAb) developed by the hybridoma technology, which by all means revolutionized the face of biomedicine and overcame many drawbacks related to the use of pAbs. Nowadays, monoclonal antibodies continue to be the predominant immunoreagent although also polyclonal antibodies still retain their share of the applications and market [1]. While some modifications and improvements in the preparation of monoclonal and polyclonal antibodies, such as various immunization strategies [2], have been introduced over the years, the methods for generating these animal-derived antibodies have not significantly improved in the past 40 years [3]. Moreover, validation of monoclonal and polyclonal antibodies is often lacking, which can be seen as a major limitation considering the quality and consistency of antibody-based technologies [4].

On the other hand, the emergence of recombinant antibody technologies over the last decades has enabled the production of antibodies without the need for animal immunizations. Such non-animal-derived antibodies are produced from 
synthetic or naïve (non-immunized) antibody repertoires, which do not require animal immunization at any stage of the library construction or antibody production. Various display methods, most notable one being phage display which was awarded with the Nobel Prize in Chemistry in 2018 to George P. Smith and Sir Gregory P. Winter [5], provide a straightforward methodology for guided selection of appropriate binders. Antibody production by phage display employs the same mechanistic principles as the immune system and results in antibodies that are functionally indistinguishable from those produced in vivo. Non-animal-derived antibodies that encompass various formats, including antibody fragments, such as fragment antigen-binding (Fab), single-chain fragment variable $(\mathrm{scFv})$, and full-length antibody or other engineered variants, are now emerging as credible alternatives for monoclonal antibodies [6]. Even though antibodies originating from phage-displayed repertoires are still far behind monoclonals, it is noteworthy that in 2020 already more than 70 phage-derived mAbs have entered clinical studies, and 14 of them have been approved [7].

Even though synthetic and naïve antibody repertoires are now capable of outweighing the obsolescent animal immunization protocols, the majority of antibodies used in research are still made by immunizing animals, most frequently rabbits or mice. Antibody production requires the use of a considerable number of animals with substantial animal welfare consequences. It has been estimated that almost 1 million animals are used annually for antibody production in the EU alone [3]. In accordance with the EU directive 2010/63/EU on protecting animals used for scientific purposes [8], the EU Reference Laboratory for alternatives to animal testing (EURL ECVAM) published new recommendations on non-animal-derived antibodies in 2020 [3]. The recommendation clearly states that "animals should no longer be used for the development and production of antibodies for research, regulatory, diagnostic and therapeutic applications" [3]. In particular, antibody production using the ascites method should not be acceptable under any circumstances. Accordingly, the manufacturers should replace animal-derived antibodies in their selection and label unambiguously whether the antibodies in their catalogues are animalderived or not.

Despite this clear missive from the EU experts, many scientists are reluctant to give up on the use of animal-derived antibodies, and to a large extent, the EURL ECVAM recommendation has been plagued with criticism. There is an ongoing debate in the scientific community on the use of animalderived antibodies and the readiness of the technologies to produce non-animal-derived antibodies [9-11]. While some are posing non-animal-derived antibodies to supersede monoclonal and polyclonal antibodies, others argue that the required technology is not quite there yet and non-animalderived antibodies should complement rather than replace monoclonal antibodies. In this review, we discuss the potential of recombinant antibodies for their application in rapid screening immunoassays and biosensors for the analysis of food samples with special emphasis on the detection of biotoxins, antibiotics, pesticides, and foodborne pathogens.

\section{Conventional antibodies}

\section{Antibody structure}

Antibodies are produced by the immune system of vertebrates as a defense mechanism against foreign or harmful agents, such as pathogenic bacteria, viruses, toxins, and the like. In the body, antibodies recognize, bind, and mark their target antigens for removal, for example, by neutralization or via phagocytosis. Antibodies, also referred to as immunoglobulins, are classified into five isotypes, $\operatorname{IgA}$, $\operatorname{IgD}$, $\operatorname{IgE}, \operatorname{IgG}$, and $\operatorname{IgM}$, based on their heavy chain constant domains [12]. IgG is the most commonly used isotype and the most prevalent in human, comprising $80 \%$ of serum antibodies. These antibodies are very stable and easily purified by affinity chromatography with protein A or protein $\mathrm{G}$, making IgGs the most important antibody isotype for biotechnological and medical applications $[12,13]$.

In terms of structure, antibodies have been among the most studied of all proteins [14]. The Y-shaped structure of the IgG molecule, with a molecular weight of about $150 \mathrm{kDa}$, consists of two identical heavy chains and two identical light chains, both of which have variable and constant domains (Fig. 1a). The highly conserved stem of the $\mathrm{Y}$, known as the Fc region (for fragment crystallizable), is responsible for interacting with cells and effector molecules [12]. Within each variable domain, the complementary determining regions (CDRs), or hypervariable loops, form the antigen-binding site. This region is responsible for the vast recognition variety and exquisite specificity of the IgGs, which is achieved by a high sequence variation through combinatorial assembly of the gene segments. During B-cell development, these genes are irreversibly joined by DNA recombination to form a complete variable region with enormous diversity potential. Furthermore, in the process of joining the gene segments, additional junctional diversity is formed by adding or subtracting nucleotides. The complete antigen-binding site is finally created by pairing the variable regions of both heavy and light chains, each composed of distinct gene sets, and as a result, antibodies gain the apparently infinite variety of subtly different forms that allow them to recognize specifically a huge number of different antigens $[12,16]$.

\section{Polyclonal and monoclonal antibodies}

Polyclonal antibodies are produced by injecting the antigen of interest into an animal and collecting the serum as a source of antibodies some weeks after the immunization. Most 


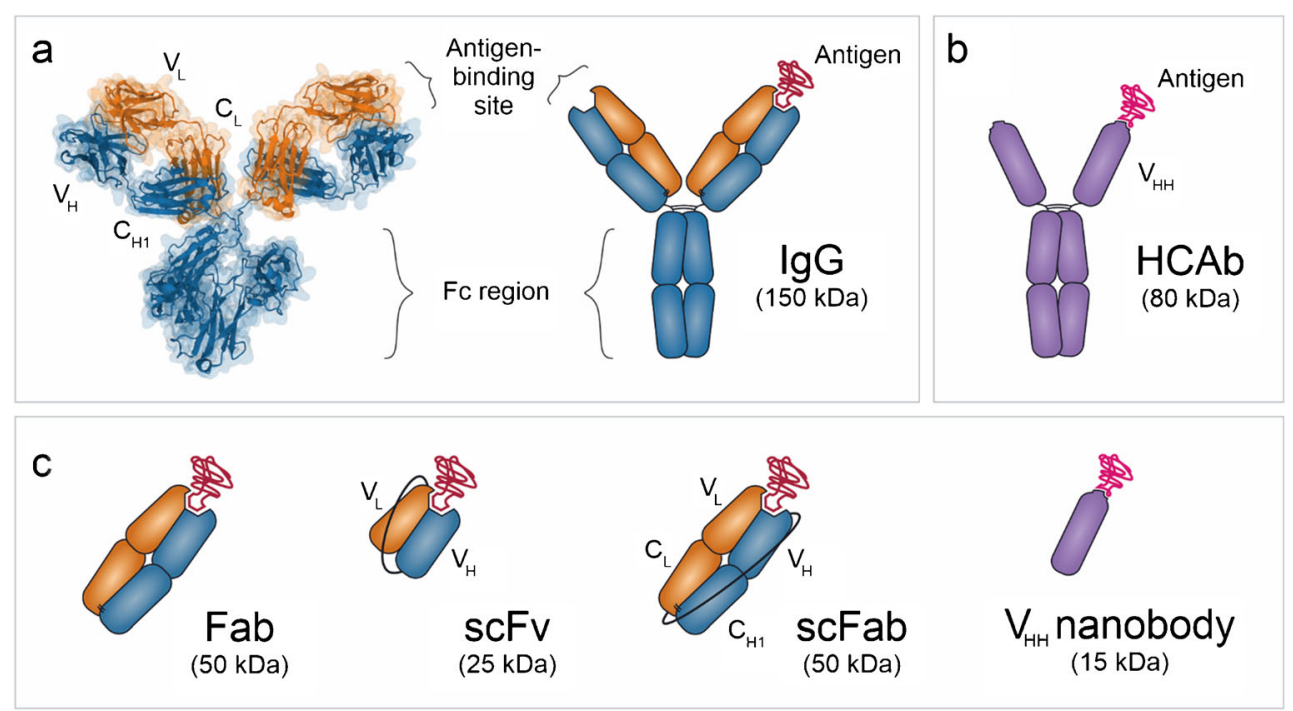

Fig. 1 a Structure of a typical $\operatorname{IgG}$ antibody depicted as a molecular model (PDB ID 1IGY; Mol* [15] RCSB PDB, https://www.rcsb.org) and as a schematic representation. The whole $\operatorname{IgG}$ antibody of about $150 \mathrm{kDa}$ is made up of four peptide chains, two identical heavy chains (blue) and two light chains (orange). The constant Fc-region forms the stem of the antibody molecule whereas the antigen-binding sites are formed by the two variable domains $\left(\mathrm{V}_{\mathrm{L}}\right.$ and $\left.\mathrm{V}_{\mathrm{H}}\right)$. b Structure of the heavy chain antibody $(\mathrm{HCAb})$ which naturally is devoid of light chains and is capable of antigen recognition solely by one single domain, the

commonly used animal species include rabbit, mouse, rat, hamster, and guinea pig. When larger amounts of antibodies are required, larger farm animals, such as sheep or goats, are often used [17]. The blood of the immunized animal is collected to monitor the antibody response and obtain the polyclonal sera, and finally, exsanguination is performed under general anesthesia, usually by heart puncture, which results in the death of the animal. Despite their wide and continuing use, polyclonal antibodies have several limitations. Polyclonal antibodies provide a finite supply of antibodies, and each batch is unique because immunizing an animal never results in an identical mixture of antibodies [18]. Yet, polyclonal antibodies are relatively inexpensive and quick to produce without the need of specialized skill or equipment, and they can function as excellent recognition elements because they usually have a high overall affinity against their target. For some targets, polyclonal antibodies are the only available antibody type, and they are widely used, for example, as secondary detection antibodies in numerous applications [19]. Nevertheless, this kind of antibodies always represents a mixture of different antibodies that recognize several epitopes of the target as well as unknown targets. In fact, according to some reports, only around $0.5-5 \%$ of antibodies in the serum sample of an immunized animal bind to the intended target [20]. This can result in high background signals or crossreactivity in immunological methods, if the antibodies are not affinity purified against the target they recognize. Moreover, production of polyclonal antibodies is inherently variable heavy domain $\left(\mathrm{V}_{\mathrm{HH}}\right)$. The HCAb depicted in the figure with two constant domains is derived from Camelidae family (shark-derived HCAbs are constituted by 5 constant domains). c Antibody fragments $\mathrm{Fab}$ (for fragment antigen-binding), $\mathrm{scFv}$ (for single-chain variable fragment), and $\mathrm{scFab}$ (for single-chain $\mathrm{Fab}$ ) retain the antigen-binding site of the intact IgG but lack some or all of the constant domains making them significantly smaller in size. The single-domain antibody derived from $\mathrm{HCAb}$, known as the $\mathrm{V}_{\mathrm{HH}}$ or nanobody, represents the smallest available antibody fragment with functional antigen binding.

dependent on the use of animals for immunization and source of antibodies.

In the 1970s, the hybridoma technology created by Köhler and Milstein [21] revolutionized the way of making antibodies. Monoclonal antibodies are made by fusing a normal short-lived antibody-producing B cell with a cancer cell line. Production of antigen-specific $\mathrm{B}$ cells requires also immunization of the animal, most often mouse, rat, or hamster, with the antigen under study. The B-cells are harvested from the spleen by sacrificing the animal generally after several booster immunizations. Antibody-producing B cells from the spleen are then fused with non-secreting myeloma cells (hybridoma cells), and the product is cloned and tested for antigen specificity $[2,17]$. The resulting hybridomas are, in theory, capable of producing only one identical antibody clone, i.e., a monoclone, which is a significant advantage over polyclonal antibodies. Moreover, monoclonal antibodies are capable of recognizing very specific and unique epitopes with high affinity and reduced probability of cross-reactivity. In addition, hybridoma cell lines have the capacity of producing large quantities of the identical antibody without batch-to-batch variations, thus overcoming some of the major limitations of polyclonal antibodies. However, also monoclonal antibodies can be contaminated with additional unwanted antibody chains, and even hybridoma cell lines are not infinite; they can die off or lose their antibody genes [19, 20]. Monoclonal antibodies are also significantly costlier to produce than polyclonals. Their production can be not only tedious and time-consuming but also require considerable skills 
and training. Moreover, despite their superior specificity over polyclonal antibodies, numerous reports have also shown the lack of specificity of monoclonal antibodies. Even many commercial monoclonal antibodies can react with more than one target as well, which often arises from an additional antibody chain in the hybridoma cell [22].

Polyclonal and monoclonal antibodies have been the cornerstone of immunological methods for decades, yet they pose several intrinsic limitations. Sometimes, whole antibodies result in practical drawbacks, such as slow and costly production, low stability, slow kinetics, or weak tissue penetration. Indeed, although highly effective, monoclonal and polyclonal antibodies are laborious and expensive to produce, they require the use of animals, and they result in non-human and potentially immunogenic antibodies, which is a major concern depending on the final application (e.g., for antibody therapeutics). In addition, the natural immune system imposes restrictions complicating the production of antibodies against unstable antigens, highly conserved proteins between species, or toxic compounds. Although researchers have tried to overcome these limitations by different strategies, including the generation of human antibodies in transgenic mice designed to produce a repertoire of human immunoglobulins followed by hybridoma, some of these caveats still persist [23]. The advantages, limitations, and key differences of different antibodies are presented in Table 1 .

\section{Recombinant antibodies}

\section{Origin and characteristics}

Recombinant antibodies $(\mathrm{rAb})$ are generated by recombinant DNA technologies, and they can offer several advantages over polyclonal and monoclonal antibodies (Table 1). In contrast to glycosylated whole antibodies, recombinant antibody fragments can be produced in bacterial cells [25]. Since recombinant antibodies are based on a known and defined DNA sequence, their production is highly reproducible and low cost. Moreover, recombinant antibodies can be engineered further, for example, with different affinity tags to facilitate their purification or immobilization for the downstream applications [26]. Alternatively, recombinant binders can be multimerized to increase their avidity.

Recombinant antibodies can originate from various sources; and thus, they are not always truly animal-free. For example, a known sequence of the monoclonal antibody can be used to construct recombinant antibody fragments by direct cloning of the gene fragments from the hybridoma cell lines. Despite the fact that at that point, such antibody fragments can be readily produced for example in Escherichia coli without the use of animals, the generation of the parental monoclonal antibody still requires animal immunization; and thus, such recombinant antibodies are considered animal-derived. In some cases, isolation of functional recombinant antibody fragments from hybridoma cell lines can be challenging, and the fragments might have lower affinity than their parental monoclonal antibody [27, 28].

Alternatively, phage-displayed antibody repertoires (either as naïve or engineered libraries) provide an actual alternative to circumvent some of these caveats, especially regarding animal immunization. In vitro selection methods by means of phage display can be used to get antibodies against almost any target in a high-throughput or even automated manner [29]. In addition, in vitro selection can offer a more precise control over the selection of antibodies against toxic targets or unstable proteins, or regarding their affinity maturation, if needed [30, 31].

Phage display technology was originally developed by George P. Smith in 1985 [32], and since then it has become the most widely used selection method for human antibodies thanks to the breakthrough achievements made by Sir Gregory P. Winter [5]. This technology is used to generate
Table 1 Comparison of different antibody types and their advantages and limitations. Adapted from [24]

\begin{tabular}{llll}
\hline & Polyclonal $(\mathrm{pAb})$ & Monoclonal $(\mathrm{mAb})$ & Recombinant (rAb) \\
\hline $\begin{array}{llll}\text { Production } \\
\text { - Time }\end{array}$ & Short $(3-4$ months) & Long (up to a year) & Short to moderately long \\
- Cost & Low & Moderate to high & Low to high \\
- Ease & Very easy & Difficult & Easy \\
Targets & Immunogenic targets & Immunogenic targets & No limitations \\
Stability & High & Moderate & Depends on the format \\
Reproducibility & Limited & Virtually reproducible & Fully reproducible \\
Specificity & Moderate & High & High \\
Sensitivity & Variable & Moderate to high & High \\
Engineering & Not possible & Only after converting to rAb & Possible \\
Availability & Commercially & Commercially available & Limited commercial availability \\
& available & & \\
\hline
\end{tabular}


and/or affinity maturate antibodies for research and medical use $[33,34]$. In phage display, antibody pools displayed on phages (synthetic or constructed from human or immunized or naïve animals) are subjected to in vitro selection with the immobilized target of interest on plates or in solution. Specific clones bound to the target are then amplified after infection of bacterial cells and directly used for subsequent rounds of selection. Finally, after three or four rounds of selection, antigen-binding clones are sequenced to identify the DNA sequences of the antibodies displayed on the surface of the isolated phages. E. coli phages are the most extensively used owing to their ease of culture and rapid amplification, making their production fast and economical. This technology is now the most widely used method for generation of antibodies in vitro without the need for animal immunization. One key advantage of phage display consists of the easy manipulation, intriguing flexibility, and the potential of reformatting antibodies in order to optimize their binding properties for their targets. The selection conditions can be freely chosen, and the properties of in vitro selected antibodies can be further improved by affinity maturation after the initial selection. Moreover, selections from phage-displayed antibody libraries can be performed within a few weeks, whereas generation of the hybridoma cell lines for monoclonal antibody production inevitably takes several months. These properties together with the easy integration of conjugated or engineered phages into transduction devices have boosted their use on multiple bioassays and biosensors [35].

A plethora of antibody libraries developed in recent years has provided rapid alternatives for the antibody generation process. Immune- or non-immune natural B-cells are the usual sources to achieve the diversity of antibody libraries. In addition, the actual knowledge regarding the antibody structure has also permitted increasing the antibody diversity using synthetic DNA variety repertoire using degenerated CDRs of antibodies on a predefined antibody framework. Thus, the immunogenicity can be minimized and the need for further steps of antibody humanization can be avoided. The use of synthetic libraries allows strict control over the library design and selection procedure facilitating the identification of antibodies with preferred binding specificities. Moreover, synthetic antibody libraries can serve as the origin for truly non-animalderived antibodies.

\section{Antibody fragments}

The best-known antibody fragments are the antigen-binding fragment $(\mathrm{Fab})$ and the even smaller single-chain fragment variable (scFv) (Fig. 1c). The Fab fragment consists of the region of an antibody that actually binds to their target antigen. Fab is composed of the $\mathrm{C}_{\mathrm{H} 1}$ and $\mathrm{V}_{\mathrm{H}}$ domains of the heavy chain and the constant $C_{L}$ and the variable $V_{L}$ domains of the light chain. Conventionally, $\mathrm{Fab}$ fragments $\left(\mathrm{F}(\mathrm{ab})_{2}\right.$ and $\left.\mathrm{Fab}^{\prime}\right)$ have been generated by proteolytic digestion of animalderived monoclonal antibodies [25], but recombinant DNA technologies and protein engineering have made it possible to modify the antibody structure and develop various recombinant antibodies. The scFv format consists of the variable region of the heavy chain $\left(\mathrm{V}_{\mathrm{H}}\right)$ joined to the variable region of the light chain $\left(\mathrm{V}_{\mathrm{L}}\right)$ with a peptide linker between 10 and 25 amino acids in length. The average molecular weight of scFv is about $25 \mathrm{kDa}$; and thus, $\mathrm{scFv}$ can be easily produced in E. coli.

One advantage of using scFvs, or other recombinant antibody fragments, for biosensor development is that they can be engineered in different ways, for example, to facilitate their immobilization on the transducer surface. Several approaches have been described to this aim [36]: (1) introduction of a peptide linker containing histidines or cysteines for their immobilization on metallic surfaces, or adding positively charged amino acids, such as arginine, for derivatization of transducer surfaces negatively charged upon modification with self-assembled monolayers (SAMs); (2) introduction of a His-tag at the $\mathrm{N}$ - or C-terminus of the protein for immobilization on surfaces functionalized with Ni-iminoacetic acid (Ni-IDA), Ni-nitroloacetic acid (Ni-NTA), or Cocarboxymethylaspartate (Co-CMA); (3) conjugation of biotin to the free amines of the $\mathrm{scFv}$ for immobilization on streptavidin-modified surfaces; (4) genetic modification of the linker region of the $\mathrm{scFv}$ to contain lysines for covalent coupling to the transducer surface using carbodiimide chemistry.

Antibody fragments, such as Fab and scFv, can be used to construct phage-displayed antibody libraries. These antibody fragments usually retain the binding properties of the parental antibody while enabling high-yield production in different expression systems. In this sense, although these antibody fragments have been mostly expressed at high yield in prokaryotic expression systems, depending on the required characteristics and subsequent use of the recombinant antibody fragments, they can be expressed also in yeast and mammalian and insect cells, or in plant-based systems to increase their production while reducing costs as molecular plant farming $[24,37]$. The construction of Fab phage libraries requires the cloning of the light and heavy chain domains of antibodies rendering a molecular weight of about $50 \mathrm{kDa}$. Therefore, obtaining high-quality libraries with a high diversity is usually challenging. Furthermore, working with Fab phage display libraries can be challenging in comparison to smaller antibody fragments isolated from phage display libraries. Fab libraries have been extensively used in research pursuing mostly clinical applications $[36,38]$. The easy display of $\mathrm{scFv}$ on phages in comparison to $\mathrm{Fab}$ and their straightforward in vitro engineering for maturation have boosted the construction of phage-displayed $\mathrm{scFv}$ antibody libraries for biomedical and clinical applications, and their use in biosensors [36, 39-41]. 


\section{Single-domain antibodies}

The overall structure of antibodies is well conserved among vertebrates. Nonetheless, some deviations from the classical structure have been described consisting of only the heavy chain. Initially, heavy chain antibodies were described in the context of a pathological disorder, known as the heavy chain disease [42]. These truncated antibodies lacked various parts of the antibody, including the $\mathrm{V}_{\mathrm{L}}$ and part of the $\mathrm{V}_{\mathrm{H}}$ domain, making them incapable of target recognition. Later on, however, completely functional heavy chain antibodies which devoid of light chains were found in the sera of camel and other species in the Camelidae family (Fig. 1b) [43] and certain cartilaginous fishes [44], such as sharks [45]. These unique classes of heavy chain antibodies (HCAbs) are capable of target recognition solely by one single domain, i.e., the variable heavy domain abbreviated as $\mathrm{V}_{\mathrm{HH}}$. This domain, also referred to as nanobody or single-domain antibody, represents the smallest available antibody fragment with functional antigen binding (Fig. 1c). Single-domain antibodies are characterized by their small molecular weight (12-15 $\mathrm{kDa}$ ), high penetration in tissues, and high solubility and stability in harsh environments, such as high temperatures or denaturing conditions, as well as easy production in bacteria. Specifically, their high stability in thermally and chemically stringent conditions together with their special characteristics to form unusual paratopes and recognize native epitopes (mostly conformational epitopes, small cavities, and active sites of enzymes), which are rare for classical antibodies, has increased their use for development of new immunobiotechnological methods [46-48]. Also domain antibodies consisting of a singlevariable domain have been displayed on phages [49, 50], and in fact, highly functional phage-displayed antibody libraries can be constructed using any of these smaller antibody fragments $[51,52]$.

In addition to the advantage of small size, antibody fragments are simple to produce by various expression systems, such as $E$. coli where production of antibody fragments is simple and economic. However, the use of single-domain antibodies has shown some limitations for the analysis of low molecular weight analytes, such as mycotoxins, pesticides, or antibiotics, which have been attributed to the lack of a light chain that is present in conventional and other recombinant antibodies. More efforts are needed to investigate the structure of the nanobody and the recognition mechanism of small haptens using, for example, nuclear magnetic resonance (NMR) and crystallization techniques. The knowledge of such interaction patterns would allow a more effective design of nanobodies applying antibody maturation techniques, as well as of the immunogen applied for antibody generation [53].

\section{Other synthetic antibody mimics}

The unique properties of antibodies have provided inspiration for active research in antibody engineering trying to downsize the antibody molecule, even further than single-domain antibodies or nanobodies. In this sense, synthetic antibody mimics generated entirely in vitro, and thus completely eliminating animals from the production process, have been the focus of many research groups in recent years. Such antibody mimics include cyclic peptides joint to a scaffold mimicking the antibody paratope (peptidomimetics), nucleic acid aptamers, molecularly imprinted polymers, non-immunoglobulin protein scaffolds, or even in silico designed recognition elements that have been applied to the development of biosensors showing good selectivity and sensitivity for the analysis of different targets in various fields [54-59]. As a consequence of their in vitro production, the antigen recognition site can be theoretically engineered to recognize any desired target.

In this regard, the use of aptamers for food analysis has been extensively explored in the literature [59]. Some of the advantages of aptamers over antibodies include high stability under a wide $\mathrm{pH}$ range and temperature, long shelf-life and ease of transportation, ease of chemical modification, production reproducibility, simple regeneration after denaturalization, and access to protein epitopes of limited access by antibodies. However, the affinity of aptamers for certain type of molecules, especially those containing hydrophobic and negatively charged parts, is not always high and cross-reactivity issues are a limitation in some cases.

\section{Application of recombinant antibodies in food analysis}

\section{Mycotoxins}

Mycotoxins are toxic compounds produced naturally by some genera of fungi, which can grow in the field or during harvesting, drying, or improper storage of certain crops, including cereals, fruits, seeds, or nuts [60]. They can cause acute or chronic diseases and disorders, known as mycotoxicosis, in humans and animals, as well as significant economic losses. Nowadays, around 300-500 different mycotoxins have been characterized, although, according to current research, the real number of these compounds can be significantly higher [61]. Several national and international authorities, including the EU and the US Department of Agriculture, have set regulatory and legislative limits for the main mycotoxins in different food and feed commodities [62]. However, the fulfilment of these limits is problematic in developing countries where contamination is endemic, and the population is exposed to mycotoxin concentrations in food that would not be acceptable in developed countries [61]. In this context, there is a great interest of 
developing simple, fast, and robust analytical methods that can be applied for multi-mycotoxin and/or in-field analysis at low cost. In this regard, antibody-based techniques are especially suitable for point-of-use analysis, and although pAbs and $\mathrm{mAbs}$ continue to be the most commonly used antibodies $[59,63]$, the search of new and sensitive rAbs for mycotoxin analysis has experienced a great focus of attention in the past decade [64].

Table 2 collects the characteristics of selected rAbs developed for the analysis of mycotoxins in food since 2015. Most of them describe the application of novel rAbs to the development of ELISA-based methods or homogeneous assays [27, 53, 67, 75] with good sensitivities and selectivities in comparison to the application of animal-derived antibodies [53, 89, 90]. In fact, rAbs have shown to be especially suited for mycotoxin analysis because the small size and toxicity of these molecules sometimes make it difficult to generate natural antibodies against them [19]. Lateral flow assays [68, 70] and immunosensors [87] with rAbs have been described as well; however, applications in these areas are still scarce. In fact, test kits using rAbs have not been commercialized so far for food analysis [19]. Therefore, more efforts should be focused on the generation of new immunodetection formats to broaden the applicability of rAbs for mycotoxin detection.

As shown in Table 2, different anti-idiotypic (anti-ID) antibodies have been developed for their use as antigen surrogates, in replacement of mycotoxin-carrier proteins or toxin-conjugated enzymes in immunoassays [71, 78-80, 83]. Anti-ID antibodies, also known as Ab2, bind to the $\mathrm{CDR}$ region (idiotype) of the primary anti-target $\mathrm{Ab}$ (named as Ab1) $[19,91]$. Such antibodies thus mimic the epitope of the target antigen and can replace the hapten-protein conjugates conventionally used in competitive immunoassays and improve the assay performance. Phage-displayed antibody libraries have been used to select various anti-ID antibodies for the detection of contaminants in food [73, 85-87]. For mycotoxin detection, several anti-ID- $\mathrm{V}_{\mathrm{HH}}$ antibodies have been reported. Some of the advantages of anti-ID- $\mathrm{V}_{\mathrm{HH}}$ for these applications include [68] (a) easy engineering due to their small size; (b) higher solubility and chemical stability than animal-derived antibodies, which helps minimize the matrix effects; (c) interactions mainly based on main-chain rather than on side-chain contacts; and (d) easy large-scale production. In comparison with traditional ELISAs, the sensitivity of these assays is usually significantly better $[71,78$, 80].

For example, the use of a phage-displayed anti-ID- $\mathrm{V}_{\mathrm{HH}}$ isolated from a naïve alpaca $\mathrm{V}_{\mathrm{HH}}$ library, with great affinity to an anti-zearalenone (ZON) $\mathrm{mAb}$, provided a 26-fold improvement in the sensitivity in comparison with a competitive ELISA using bovine serum albumin (BSA)-conjugated ZON [83]. In order to decrease the detection limit, the phage particles bound to the 96-well microtiter plates were eluted after the assay and applied as templates for immunopolymerase chain reaction (IPCR). In comparison with the $\mathrm{V}_{\mathrm{HH}}$ phagebased ELISA, the IPCR approach allowed a 12-fold improvement in the limit of detection $(6.5 \mathrm{pg} / \mathrm{mL}$ vs $0.08 \mathrm{ng} / \mathrm{mL})$ and a wider linear range; however, the reproducibility of the assay decreased (RSD: 5.5-28.1\%). High sensitivities (9-fold improvement) were also achieved for the analysis of ochratoxin $\mathrm{A}(\mathrm{OTA})$ using phage-displayed anti-ID- $\mathrm{V}_{\mathrm{HH}}$ and IPCR (LOD $4.17 \mathrm{pg} / \mathrm{mL}$ ) [73] in comparison with conventional phage-based ELISA, improving the performance of other rAbs for OTA detection [75-77]. This amplification technique has also been applied in combination with phagedisplayed $\mathrm{V}_{\mathrm{HH}}$ for the detection of different mycotoxins [53].

In another example, Tang et al. [68] reported the application of a time-resolved fluorescence immunochromatographic assay (TRFICA) using Eu/Tb(III) nanospheres, labelling either an anti-toxin $\mathrm{mAb}$ (mAb-TRFICA) or the anti-ID- $\mathrm{V}_{\mathrm{HH}}$ (anti-ID- $\mathrm{V}_{\mathrm{HH}^{-}}$-TRFICA), for the simultaneous analysis of ZON and aflatoxin $\mathrm{B}_{1}\left(\mathrm{AFB}_{1}\right)$. The anti-ID- $\mathrm{V}_{\mathrm{HH}}$-TRFICA showed an 18.3 and a 20.3 higher sensitivity, for $\mathrm{AFB}_{1}$ and ZON, respectively, than the mAb-TRFICA approach. This behavior was attributed to the longer interaction between the mycotoxin and the corresponding $\mathrm{mAb}$ before competition with the anti-ID- $\mathrm{V}_{\mathrm{HH}}$ immobilized on test line of the immunochromatographic strip. In the mAb-TRFICA approach, competition between the labelled antigen and the free toxins for the binding sites in the $\mathrm{mAb}$ took place on the test line resulting in lower sensitivities. The method was successfully applied to the analysis of both toxins in naturally contaminated maize samples and validated by LC-MS/ MS.

Further improvements in the sensitivity of competitive assays for the detection of mycotoxins have been proposed using site-directed mutagenesis of antigen-mimicking nanobodies. Deoxynivalenol (DON) has been detected using phage-displayed anti-ID- $\mathrm{V}_{\mathrm{HH}}$ mutants [79] obtained upon site saturated mutagenesis of five amino acids identified at the binding site of a DON-mimicking $\mathrm{V}_{\mathrm{HH}}$ selected by phage display [78]. Competitive ELISAs using the mutants were up to 3.2 times more sensitive than those using the wild type. Nevertheless, it was necessary to apply a large-scale screening process to obtain high-affinity mutants; thus, an alternative strategy to improve the sensitivity of the competitive immunoassays would be in search of lower-affinity nanobodies. Moreover, the selection of the positions for mutagenesis will significantly affect the results and sometimes the mutation of the amino acids close to the key ones allows very effective modifications.

Several studies have shown that the use of alkaline phosphatase (AP) fusion proteins ( $\left.\mathrm{scFv}-\mathrm{AP}, \mathrm{V}_{\mathrm{HH}}-\mathrm{AP}\right)$ in replacement of free $s c F v$ or $\mathrm{V}_{\mathrm{HH}}$ fragments usually results in competitive ELISAs with better detection limits, shorter 


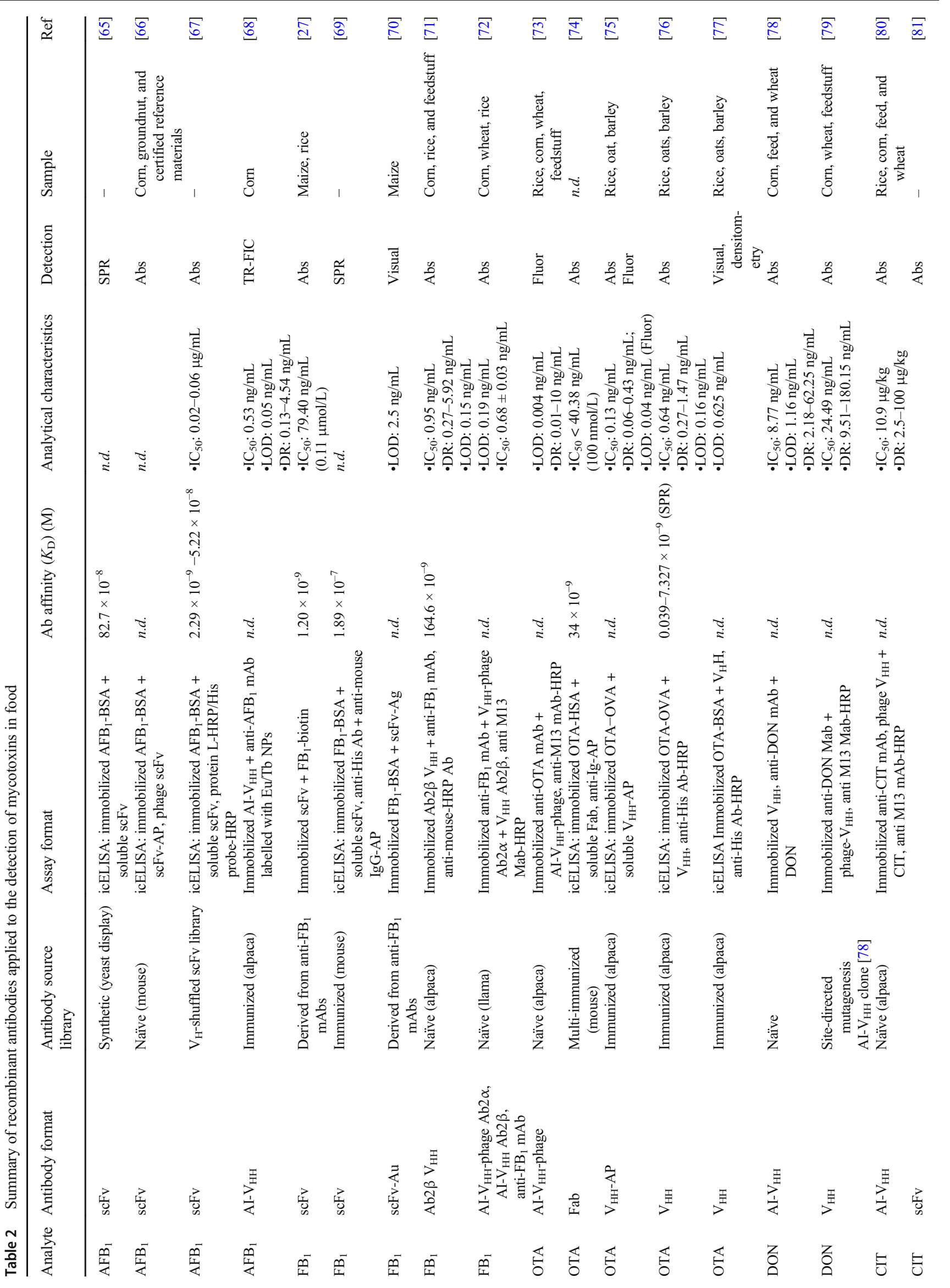



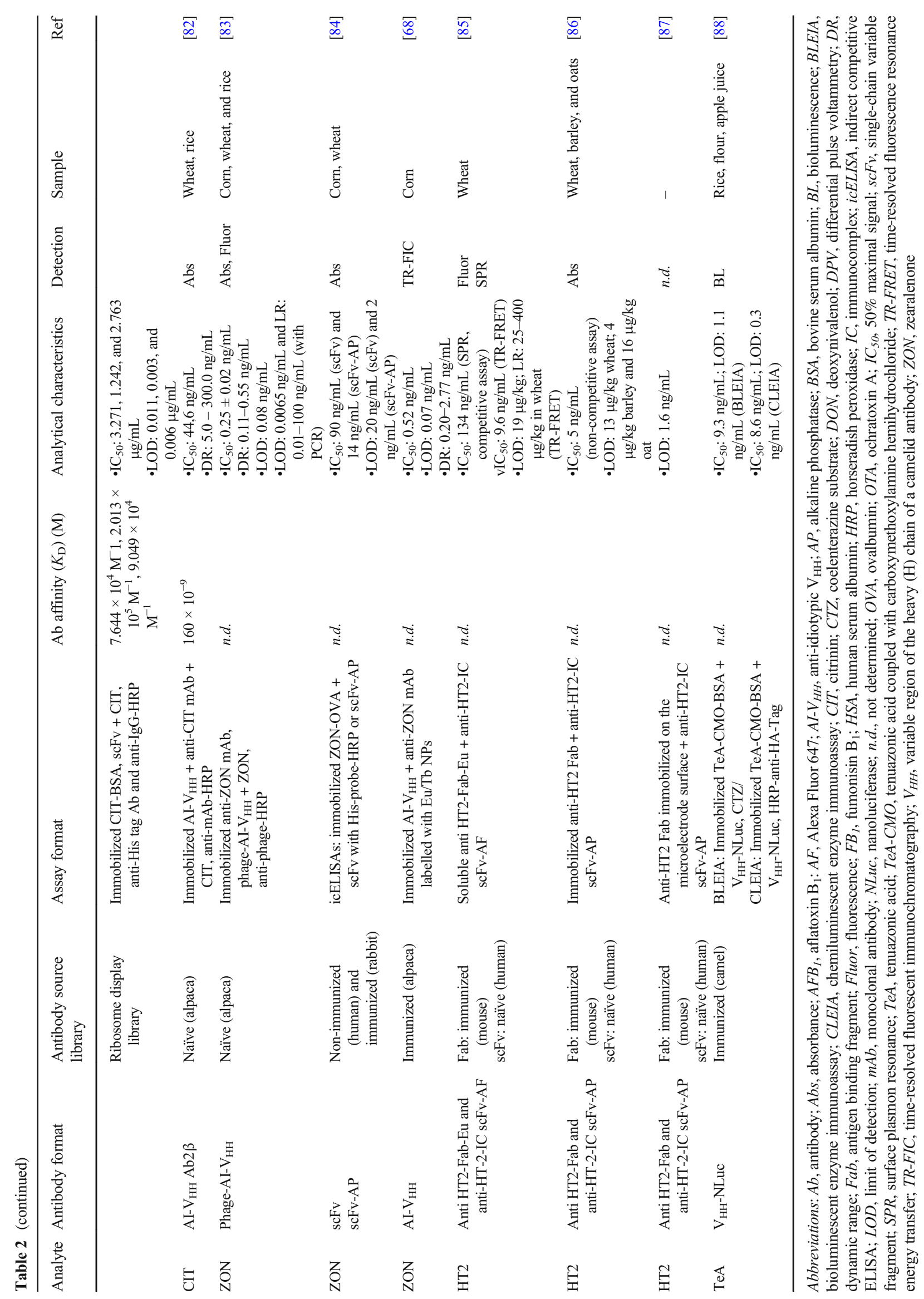
analysis times, and reduced variability, due to the elimination of one assay step when compared with an indirect ELISA [75, 84]. This effect is attributed to an avidity effect since AP exists as a dimer in solution; therefore, the antibody fragments would also bind effectively as dimers [40].

Furthermore, the use of recombinant antibody techniques has enabled the development of antibodies that can be applied in non-competitive assays for the detection of the target compound. Usually, non-competitive immunoassays can provide better analytical characteristic in terms of sensitivity, dynamic range, and selectivity than competitive assays. This approach has been applied, for example, to the detection of fumonisin $\mathrm{B}_{1}\left(\mathrm{FB}_{1}\right)$ using two types of anti-ID nanobodies isolated from a naïve phage display library [72]. One of them, $\mathrm{Ab} 2 \alpha$, recognized an epitope far from the binding site of the toxin and the other, $\mathrm{Ab} 2 \beta$, competed with $\mathrm{FB}_{1}$ for the antibody binding. In the presence of the target, the phage-displayed $\mathrm{Ab} 2 \alpha$ does not bind to $A b 2 \beta-A b 1$ complex due to steric hindrance. The detection was carried out using an HRP-conjugated anti-phage antibody. This approach has allowed an over 17-fold improvement in the LOD in comparison with a competitive ELISA $(0.19 \mathrm{ng} / \mathrm{mL}$ vs $3.41 \mathrm{ng} / \mathrm{mL})$ with a good selectivity in the presence of other toxins different from fumonisins and other primary antibodies.

Another alternative for developing non-competitive immunoassay for low molecular weight targets is the use of anti-metatype antibodies, i.e., anti-immune complex (antiIC) antibodies that bind to the primary antibody only when it is bound to the antigen. Arola et al. [85-87] demonstrated the applicability of an anti-IC-scFv against HT-2 toxin and a recombinant anti-HT-2 Fab, isolated from naïve scFv and immunized phage libraries, respectively, for the analysis of the toxin in cereal samples. One advantage of this approach was that although the primary anti-HT-2 Fab cross-reacted with T-2, a toxin from the same family, the anti-IC-scFv allowed the development of selective non-competitive assays for HT-2 toxin. As shown in Fig. 2a, the antibody fragments were applied in homogeneous time-resolved Förster resonance energy transfer (TR-FRET) assays by labelling the primary antibody, anti-HT-2 Fab, with europium as the donor and the anti-IC-Fab with Alexa Fluor 647 as the acceptor. Alternatively [86], the detection was based on a heterogeneous ELISA using a biotinylated anti-HT-2 Fab immobilized on streptavidin-coated microwells and a scFv-AP fusion specific for the IC (Fig. 2b). The LOD of both assays was similar ( 0.38 and $0.3 \mathrm{ng} / \mathrm{mL}$ for the FRET and enzyme-based assays, respectively), although the first approach had the advantage that the hands-on time for the user was minimized as it did not require immobilization, washing, and separation steps. The FRET-based assay was 13 times, while the AP-based was 10.8 times more sensitive than a competitive ELISA demonstrating the usefulness of anti-IC Abs for this application.

\section{Foodborne pathogens and other biotoxins}

The main pathogens that contaminate foodstuff include bacteria, viruses, parasites, fungi, and prions. They are responsible of adverse health effects ranging from mild (e.g., diarrhea or vomiting) to severe (e.g., septicemia, liver or kidney damage, hemorrhagic colitis), or even life-threatening. Some of these microorganisms, such as bacteria and fungi, can release toxic compounds into the food that are resistant to inactivation during food processing, leading also to food poisoning [92]. The applications of rAbs for mycotoxins analyses have been reviewed in the previous section, and in this section, we will focus on the detection of pathogens and other toxic targets. The most common bacteria responsible for foodborne illnesses include Salmonella spp., Campylobacter spp., Listeria monocytogenes, Staphylococcus aureus, and the diarrheic E. coli pathotypes, known as shiga-toxin producing E. coli. Parasites such as Cryptosporidium spp. and Cyclospora spp. and viruses (e.g., hepatitis A and norovirus) are also responsible for foodborne diseases [19, 93]. Contamination by microorganisms may occur during crop growth, harvesting, inappropriate storage, transport, postprocessing adulteration or distribution, and their growth and survival are affected by climatic factors, with an increment in the replication cycles with increasing temperatures.

According to the World Health Organization [93], the most commonly reported zoonosis since 2005 in the EU is campylobacteriosis followed by salmonellosis. In fact, the past two decades have witnessed an increment of bacterial infections due to the increased consumption of fresh products, following the recommendations for a healthy diet, in Europe and North America [94]. The most widely applied techniques for microbial detection still involve culture and microscopy $[95,96]$, but they are time-consuming and require skilled personal and substantial efforts. Alternative approaches, such as PCR, immunological or proteomic-based methods, and biosensors, have also been reported in an effort to improve pathogen detection and reduce the analysis time. The use of bacteriophages as recognition elements for bacterial detection has received an important attention in the last decade [35, 97], but not many rAbs have been reported for this application. However, as described below, there are many examples of their use in the implementation of assays for the analysis of bacterial, aquatic, and marine toxins. Table 3 shows the characteristics of selected rAbs developed for the analysis of these contaminants in food since 2015.

As described in the literature, immunodetection of S. aureus has been hampered by the unspecific and undesirable interaction between staphylococcal protein $\mathrm{A}(\mathrm{SpA})$, an immunoglobulin-binding protein of the surface of the bacteria, and the $\mathrm{Fc}$ region of most mammalians immunoglobulins that results in false positive signals [99, 103]. The use of nanobodies has been proposed as an alternative to avoid such 
(a)
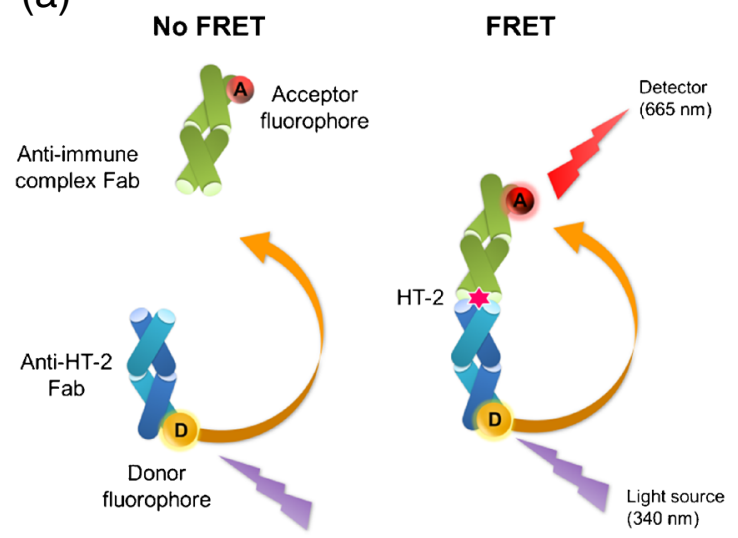

(b)

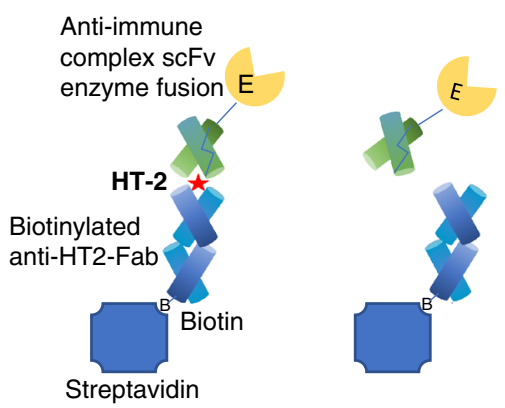

Fig. 2 Principle of the non-competitive immune complex ELISAs for the detection of HT-2. a Homogeneous immunoassay based on FRET between the anti-HT-2 Fab labelled with the donor fluorophore and the anti-immune complex Fab labelled with the acceptor in the presence of the toxin. Reprinted with permission from reference [60]. b
Heterogeneous ELISA where the anti-immune complex single-chain variable fragment alkaline phosphatase fusion ( $\mathrm{scFv}-\mathrm{AP}$ ) binds to the immobilized anti-HT-2 Fab in the presence of HT-2 toxin. Adapted from reference [86]

alternative tool for the identification of novel biomarkers together with the production of selective antibodies for bacterial detection that can be of interest for commercial applications.

Staphylococcal enterotoxin B (SEB) is the most potent toxin produced by $S$. aureus that shows high stability and high toxicity even at very low concentrations. Several analytical techniques have been implemented for the analysis of SEB in food, including commercial ELISA kits which are commonly applied in routine analysis [103]. However, as discussed previously, the presence of SpA in the sample may result in false positives that will have a negative impact on the analysis of SEB. The use of nanobodies specific to SEB has allowed overcoming this limitation using a sandwich assay with anti-SEB nanobody as capture antibody and a phagedisplayed anti-SEB nanobody as the detection element. The assay provided an LOD approximately one-half lower than the conventional mAb-based ELISA (0.3 vs $0.69 \mathrm{ng} / \mathrm{mL}$ ) and a much wider dynamic range $(1-512 \mathrm{ng} / \mathrm{mL}$ vs $2-64 \mathrm{ng} / \mathrm{mL})$, due to the signal amplification resulting from the use of HRPlabelled anti-phage antibody for detection. The assay showed a low cross-reactivity to staphylococcal enterotoxin C (SEC) but none to staphylococcal enterotoxin A (SEA) or to SpA, avoiding the false positive problems described previously. The substitution of the capture nanobody by a mAb and of the detection phage-nanobody by an anti-SEB nanobody-AP fusion and chemiluminescent detection did not improve either the LOD $(1.44 \mathrm{ng} / \mathrm{mL})$ or the dynamic range of the assay (3.12-50 ng/mL), although the cross-reactivity in the presence of SEA was also negligible [104]. The production of singledomain antibody fragments has also been reported for the analysis of the biomarker OmpU a major protein of the membrane of $V$. parahaemolyticus, a pathogenic bacterium that can be present in raw and undercooked seafood, although the assays were not applied to food analysis [114]. 


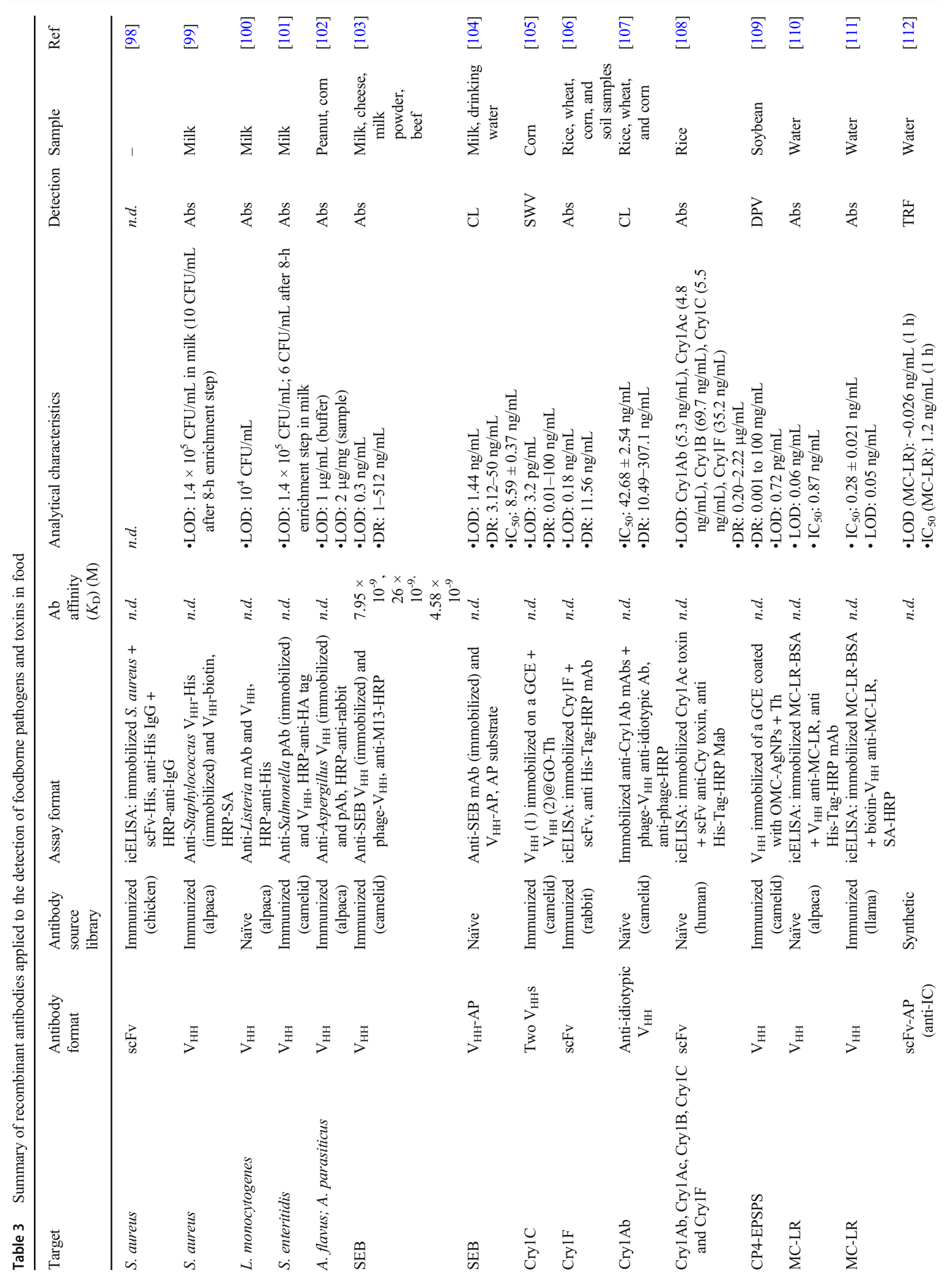




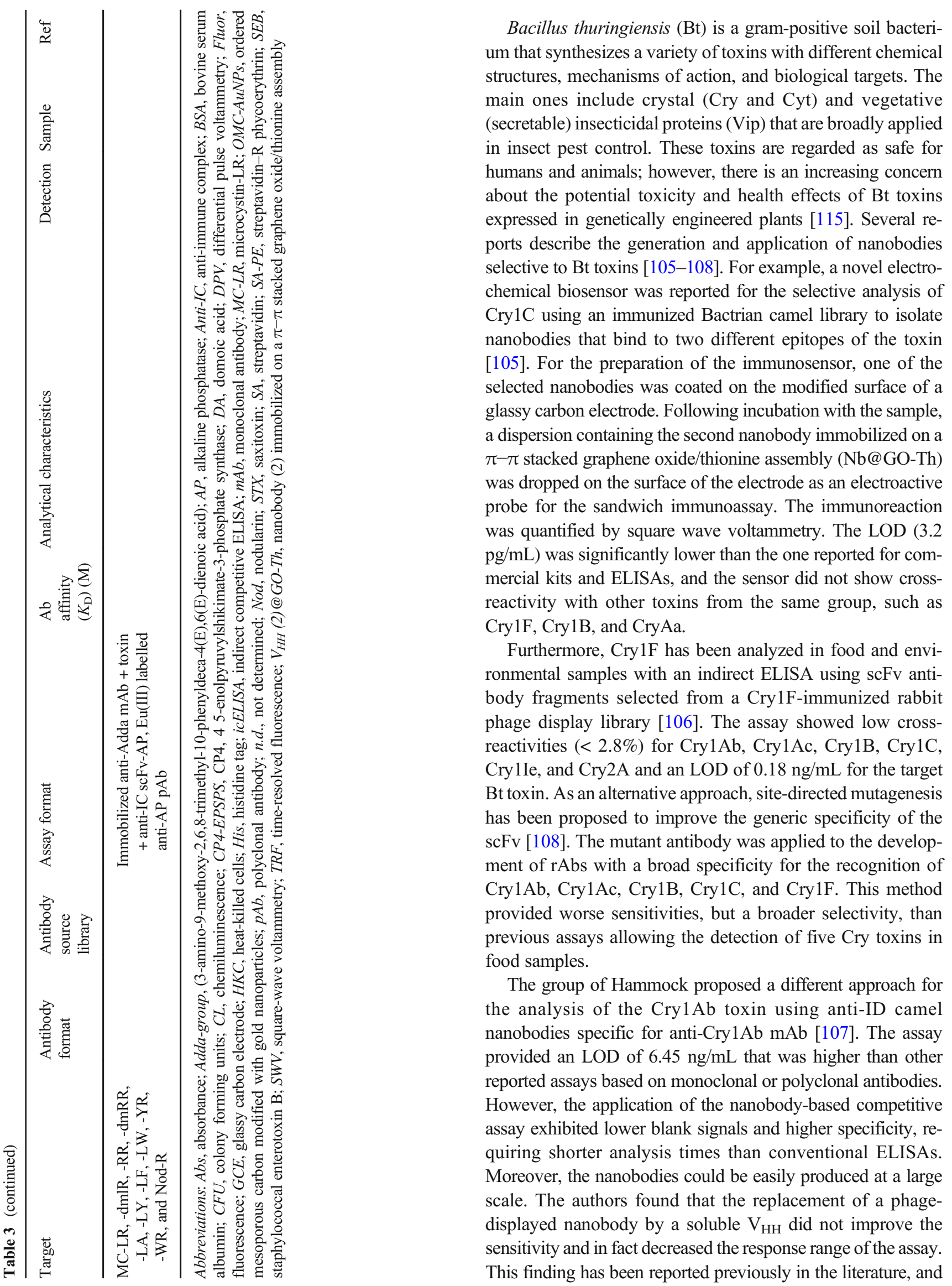


the authors propose that it could be avoided using eukaryotic rather than prokaryotic expression systems for nanobody production.

The naturally occurring Agrobacterium spp. strain CP4 encodes the CP4, 4 5-enolpyruvylshikimate-3-phosphate synthase (CP4-EPSPS) gene that confers tolerance to glyphosate. An electrochemical sensor has been developed by immobilizing the nanobody specific for CP4-EPSPS protein on the surface of a glassy carbon electrode coated with ordered mesoporous carbon modified with gold nanoparticles (OMCAuNPs) [109]. Thionine was added as the electrochemical probe for the analysis of the biomarker in soybean samples by differential pulse voltammetry (DPV) with a much better sensitivity (LOD $0.72 \mathrm{pg} / \mathrm{mL}$ ) than previous reports or commercial kits using mAbs.

Microcystins (MCs) and nodularins (Nods) are low molecular weight peptides produced by several bloom-forming cyanobacteria that can be found in freshwaters (e.g., rivers, lakes, reservoirs) after bacterial cell lysis. They can bioaccumulate in several organisms used as food sources, e.g., bivalves, crustaceans, fish, plants, or for example in algal dietary supplements and their concentration must be monitored at very low concentrations [116]. As described previously, the application of anti-IC antibodies allows the implementation of non-competitive assays for the analysis of low molecular weight targets, such as MCs and Nods. These toxins have been analyzed by time-resolved immunofluorometry [112] using a generic anti-IC-scFv, selected by phage display and fused to alkaline phosphatase (scFv-AP) to recognize the complex between $\mathrm{MC}$ or Nod and a biotinylated mAb that binds to the Adda-group (3-amino-9-methoxy-2,6,8-trimethyl-10phenyldeca-4(E),6(E)-dienoic acid) which is present in both toxins. A secondary anti-AP polyclonal antibody labelled with europium was used as a tracer to detect the interaction. The assay required a single incubation and washing step before signal generation allowing the detection of 11 toxins (MCLR, -dmlR, -RR, -dmRR, -LA, -LY, -LF, -LW, -YR, -WR, and Nod-R) with a LOD of $\sim 0.1 \mu \mathrm{g} / \mathrm{L}$ within $10 \mathrm{~min}$. Similar detection limits and sensitivities have been also reported using a competitive immunoassay and a MC-LR nanobody selected from an alpaca phage display library [110]. However, this assay provided lower cross-reactivities with other toxins different from MC-LR (between 82.7 and $116.9 \%$ only for MC-RR, MC-YR, and MC-WR). The group of González-Sapienza [111] has demonstrated the importance of the panning strategy for the selection of highly sensitive nanobodies with different cross-reactivities for the analysis of MCs. Highest affinities for the immobilized hapten were reported by selecting the phages expressing the $V_{\mathrm{HH}} \mathrm{S}$ with the slowest $k_{\text {off }}$ values $\left(\mathrm{IC}_{50} 0.28 \mu \mathrm{g} / \mathrm{L}\right.$ ).

The sequence of the variable regions of a monoclonal antibody selective to [Arg4]-MCs (MC10E7) determined by peptide mass-assisted cloning was expressed as $\mathrm{scFv}$ in yeast and as chimeric full-size antibody in yeast and tobacco leaves of Nicotiana tabacum and Nicotiana benthamiana [117]. The $\mathrm{scFv}$ fragment provided approximately16-fold lower $\mathrm{IC}_{50}$ than the full-sized mAb in the ELISA. However, the LOD obtained with the chimeric antibody, in an indirect competitive ELISA $(12.5 \mathrm{ng} / \mathrm{L})$, was only slightly lower than that of the MC10E7 antibody $(10.9 \mathrm{ng} / \mathrm{L})$, while the $\mathrm{IC}_{50}$ were $50.0 \pm$ $3 \mathrm{ng} / \mathrm{L}$ and $44.0 \pm 4 \mathrm{ng} / \mathrm{L}$ for the $\mathrm{rAb}$ and $\mathrm{mAb}$, respectively. The cross-reactivity of both antibodies was very similar (MC10E7: 58\% for MCRR; plant-derived MC10E7: 62\% for MC-RR; $<0.1 \%$ for MC-LW and MC-LF for both antibodies). The chimeric antibody was applied to the development of a lateral flow immunoassay for the detection of [Arg4]-MCs in the range of 100-300 ng/L in freshwater samples. In a different approach, the plant-derived antibody encapsulated in a sol-gel matrix was applied to the removal of MC-LR from freshwater samples in lab-scale experiments [118]. The authors point out that plant-based and microbial expression systems are attractive alternatives for the production of recombinant antibodies at large quantities and low cost.

Recombinant scFvs against two marine toxins, saxitoxin and domoic acid, have been produced using the sequence information of the corresponding mAbs [119]. The assays were implemented in a microsphere-based competitive immunoassay, and the detection limits were similar to those reported with other antibodies, although the method requires further implementation. First attempts to carry out multiplex detection were reported in food samples using a flow cytometer. Nevertheless, more work is required to avoid the crossreactivity issues found for both assays that were attributed to the non-specific binding of the scFv to the microspheres.

\section{Antibiotics}

The discovery of the first antibiotic in the mid-twentieth century changed modern medicine and treatment of most bacterial infections in both humans and animals. Today, the wide spread of drug-resistant bacteria [120] is one of the most severe threats to public health. Multidrug-resistant bacteria cause 33,000 deaths per year in Europe due to hospital infections, and additional healthcare costs of about 1.5 billion euros [121]. The inappropriate and indiscriminate use of these drugs, in both humans and farm animals, is one of the main factors behind the observed increment in the number of antibiotic-resistant bacteria. It has a significant clinical, epidemiological, and microbiological impact. Moreover, it is a global problem that affects various productive sectors, such as livestock, agriculture, the environment, trade, and, therefore, the world economy. Thus, sensitive, selective, rapid, low-cost, and easy-to-use analytical methods are required to reduce the emergence and spread of antibiotic resistance worldwide. This interest is evidenced by efforts focused on the implementation of screening methods for antibiotic control 
in the last 30 years, with immunoanalytical techniques showing the greatest impact on the market.

However, due to the small size of these drugs, there are a series of limitations for the production of polyclonal and monoclonal antibodies that limits the availability of selective and sensitive immunoassays towards these substances. In this regard, the use of recombinant antibodies can be an excellent alternative to improve the sensitivity and selectivity of the immunoassay-based methods available for antibiotic detection. The number of publications found in the last 5 years focusing on the analysis of antibiotics in food using immunochemical technologies is enormous. However, less than $7 \%$ of them utilize recombinant antibodies and in most cases engineered antibodies are used in ELISA-based methods. Table 4 collects the characteristics of selected rAbs developed for the analysis of antibiotics in foodstuffs since 2015.

As commented before, recombinant antibodies have several advantages over conventional antibodies [19]; however, some specific drawbacks have been pointed out for the production of antibiotic-specific rAbs. For example, Du et al. [127] reported a detailed comparative study of the detection of chloramphenicol (CAP) using a purified anti-CAP scFv-AP fusion protein and its parenteral mouse mAb. Two ELISA approaches, one based on the engineered $\mathrm{Ab}$ and the other on the $\mathrm{mAb}$, were implemented in parallel, and the analytical characteristics were compared in buffer and real samples. The sensitivity of the mAb-based ELISA was approximately 9 times better than the scFv-AP-based ELISA while the crossreactivity was similar in both cases. However, the CV\% obtained in the analysis of real samples with the mAb was higher than those obtained with the scFv-AP, indicating that the $\mathrm{rAb}$ could cope better with matrix effects. On the other hand, they observed the existence of many aberrant mRNAs produced by the single clonal hybridoma cell [22], approximately $32 \%$, that prevented the production of suitable mAb-derived singlechange antibody fragments. Some alternatives have been suggested to overcome this problem, like the ribozyme cleavage of aberrant sequences [129], RNaseH digestion of aberrant mRNA-DNA hybrids [130], or mRNA sequencing. Among these methods, screening of functional scFv antibodies using transcription-translation systems, such as phage display, is nowadays the preferred strategy of choice.

Li et al. [122] reported the application of a hyperimmunized chicken phage display library to screen specific binders against gentamicin (GENT). Compared with other phage display libraries, the authors proposed that the avian model allowed a simplification of rAb generation. Chicken antibodies have only one isotype light chain (lambda); and thus, chicken-derived scFvs are easier to make [131]. After the panning rounds, two anti-GENT binders (S-1, S-5) were isolated, and after the expression and purification of the scFv antibodies, indirect competitive ELISAs (icELISA) were conducted with both $\mathrm{scFv}$ variants. The sensitivity obtained with the best antibody (S-1)
( $\mathrm{IC}_{50} 12.4 \mathrm{ng} / \mathrm{mL}$ and LOD $0.15 \mathrm{ng} / \mathrm{mL}$ ) was suitable for GENT detection in food samples, such as milk, pork, beef, and chicken meat with recoveries ranging from 61 to $118 \%$ $(\mathrm{RSD}<11 \%)$.

In addition to display technologies and parenteral $\mathrm{mAb}$ gene sequencing, some authors have described further binding improvements between rAbs and their corresponding targets through homology modelling and molecular docking [27]. As shown in Table 4, specific and internal changes to the DNA sequence of pristine $\mathrm{scFv}$ have been performed by either sitedirected mutagenesis or codon optimization [124, 125]. For example, $\mathrm{He}$ et al. [124] presented an anti-amoxicillin (AMOX) $\mathrm{scFv}$ with improved recognition performance towards AMOX and 10 more penicillins. Directed mutagenesis of a pair of amino acid residues localized in the binding site pocket was changed to produce two $\mathrm{scFv}$ variants, $\mathrm{scFv}$ mutant $1\left(\mathrm{~V}_{\mathrm{L}} \mathrm{CDR} 3 \mathrm{Ser} 95 \rightarrow \mathrm{Glu}\right)$ and scFv-mutant $2\left(\mathrm{~V}_{\mathrm{L}}\right.$ CDR3 Ser95 $\rightarrow$ Glu and $V_{H}$ CDR1 Tyr160 $\rightarrow$ Arg) which were evaluated by icELISA to compare their analytical characteristics. The results indicated that both mutants preserved the recognition towards the 11 penicillins with the $\mathrm{IC}_{50}$ values between 3.1 and $16.3 \mathrm{ng} / \mathrm{mL}$. However, mutant 1 showed highly improved sensitivity of 2-6-fold in terms of the $\mathrm{IC}_{50}$ compared with native $\mathrm{scFv}$ and was used to analyze milk samples with excellent results.

Although technologies to generate recombinant antibodies against any desired target are well established, the development of immunosensors and similar platforms for the analysis of antibiotics is still limited. In this regard, Yu et al. [123] reported the development of a biosensor based on bioluminescence resonance energy transfer (BRET) as the basis for enrofloxacin (ENR) analysis using a homogeneous washfree immunosensing approach. In this work, Renilla luciferase (Rluc) was genetically fused to an anti-fluoroquinolone scFv, which acted as the energy donor and quantum dot-conjugated norfloxacin (QD-NOR) which functioned as an energy acceptor. As shown in Fig. 3, when the donor and the acceptor are in close proximity with each other, there is an energy transfer from the Rluc to the QDs via BRET. In the presence of the analyte, the Förster distance increases and energy transfer decreases. ENR was detected with an LOD of $2.54 \mathrm{ng} / \mathrm{L}$ and the dynamic range covered 4 orders of magnitude (from 0.023 to $25.6 \mathrm{ng} / \mathrm{mL}$ ). Finally, the BRET assay was applied to analyze milk samples, and five fluoroquinolones (ciprofloxacin, norfloxacin, danofloxacin, marbofloxacin, and flumequine) were successfully determined.

\section{Pesticides}

Pesticides are used to keep crops healthy and avoid devastation by diseases and plagues. They include herbicides, fungicides, insecticides, acaricides, among others. Pesticide residues pose a risk to public health; and thus, the EU and other countries in the 
Table 4 Summary of recombinant antibodies applied to the detection of antibiotics in food

\begin{tabular}{|c|c|c|c|c|c|c|c|}
\hline Analyte & $\begin{array}{l}\text { Antibody } \\
\text { format }\end{array}$ & Antibody source & Assay format & $\begin{array}{l}\text { Analytical } \\
\text { characteristics }\end{array}$ & Detection & Sample & Ref \\
\hline GENT & $\mathrm{scFv}$ & Hyperimmunized library (chicken) & $\begin{array}{l}\text { icELISA: immobilized Gent-OVA } \\
\text { + soluble scFv + anti-His } \\
\text { Ab-HRP }\end{array}$ & $\begin{array}{l}\cdot \mathrm{IC}_{50}: 12.42 \mathrm{ng} / \mathrm{mL} \\
\text {-LOD: } 0.15 \mathrm{ng} / \mathrm{mL} \\
\text { •No CR with } \\
\text { kanamycin, } \\
\text { amikacin }\end{array}$ & Abs & $\begin{array}{l}\text { Pork, beef, } \\
\text { chicken, } \\
\text { milk }\end{array}$ & {$[122]$} \\
\hline ENR & scFv-RLuc & $\begin{array}{l}\text { mRNA }\left(\mathrm{V}_{\mathrm{H}}, \mathrm{V}_{\mathrm{L}}\right) \text { isolated from } \\
\text { hybridoma cell } \mathrm{C} 49 \mathrm{H} 1 \text { producing } \\
\text { anti-FQ } \mathrm{mAb}\end{array}$ & $\begin{array}{l}\text { Immobilized NOR onto QD + } \\
\text { soluble scFv-RLuc }\end{array}$ & $\begin{array}{l}\cdot \mathrm{IC}_{50}: 1 \mathrm{ng} / \mathrm{mL} \\
\cdot \mathrm{DR}: 0.023-25.6 \\
\text { ng/mL } \\
\cdot \mathrm{LOD}: 2.54 \mathrm{ng} / \mathrm{L} \\
\quad \text { (milk after } \\
\text { sample treatment) } \\
\cdot \mathrm{CR}>60 \% \text { for up to } \\
10 \mathrm{FQs}\end{array}$ & $\begin{array}{l}\text { Fluor } \\
\text { BRET }\end{array}$ & Milk & [123] \\
\hline AMOX & $\mathrm{scFv}$ & $\begin{array}{l}\text { Directional mutagenesis of parental } \\
\mathrm{scFv}\end{array}$ & $\begin{array}{l}\text { icELISA: immobilized Amox-OVA } \\
+ \text { + His tagged soluble scFv + } \\
\text { anti-His Ab-HRP }\end{array}$ & $\begin{array}{l}\cdot \text { LOD: } 0.2-3.0 \\
\text { ng/mL } \\
\cdot \mathrm{IC}_{50}: 3.5-15 \\
\mathrm{ng} / \mathrm{mL} \\
\cdot \mathrm{CR} \%: 31-132 \% \\
\quad \text { for up to } 11 \mathrm{PCs}\end{array}$ & Abs & Milk & [124] \\
\hline SARA & $\mathrm{scFv}$ & $\begin{array}{l}\text { Directional mutagenesis of } \\
\text { parenteral scFv }\end{array}$ & $\begin{array}{l}\text { icELISA: immobilized Sara-OVA + } \\
\text { His tagged soluble scFv + } \\
\text { anti-His Ab-HRP }\end{array}$ & $\begin{array}{l}\cdot \mathrm{IC}_{50}: 3.2-63 \\
\mathrm{ng} / \mathrm{mL}(12 \mathrm{FQs}) \\
\cdot \mathrm{LOD}: 0.3-8.0 \\
\mathrm{ng} / \mathrm{mL}(12 \mathrm{FQs})\end{array}$ & Abs & Milk & [125] \\
\hline AMP & scFv-AP & $\begin{array}{l}\text { mRNA }\left(\mathrm{V}_{\mathrm{H}}, \mathrm{V}_{\mathrm{L}}\right) \text { isolated from } \\
\text { hybridoma cell 9B4C7E } \\
\text { producing anti-AMP MAb }\end{array}$ & $\begin{array}{l}\text { icCLEIA } \\
\text { Immobilized Amp-OVA + soluble } \\
\text { scFv-AP }\end{array}$ & $\begin{array}{l}\cdot \mathrm{IC}_{50}: 0.75 \pm 0.04 \\
\text { ng/mL } \\
\cdot \text { LOD: } 0.110-0.004 \\
\text { ng/mL } \\
\cdot \text { CR\% (analogues): } \\
\quad<4 \%\end{array}$ & CL & Milk & [126] \\
\hline CAP & scFv-AP & $\begin{array}{l}\text { mRNA }\left(\mathrm{V}_{\mathrm{H}}, \mathrm{V}_{\mathrm{L}}\right) \text { isolated from } \\
\text { hybridoma cell producing } \\
\text { anti-CAP MAb }\end{array}$ & $\begin{array}{l}\text { Immobilized CAP-OVA + soluble } \\
\text { scFv-AP }\end{array}$ & $\begin{array}{c}\cdot \mathrm{IC}_{50}(\mathrm{scFv}-\mathrm{AP}): \\
6.92 \pm 0.24 \\
\mathrm{ng} / \mathrm{mL} \\
\cdot \mathrm{IC}_{50}(\mathrm{mAb}): 0.74 \pm \\
0.03 \mathrm{ng} / \mathrm{mL} \\
\text { Less CR\% (MAb) } \\
\text { vs CR\% } \\
\text { (scFv-AP) }\end{array}$ & Abs & $\begin{array}{r}\text { Shrimp + } \\
\text { codfish }\end{array}$ & [127] \\
\hline NOR & $\mathrm{scFv}$ & $\begin{array}{l}\text { mRNA }\left(\mathrm{V}_{\mathrm{H}}, \mathrm{V}_{\mathrm{L}}\right) \text { isolated from } \\
\text { hybridoma cell producing } \\
\text { anti-NOR MAb }\end{array}$ & - & - & - & - & [128] \\
\hline
\end{tabular}

Abbreviations: $A b$, antibody; $A b s$, absorbance; $A M O X$, amoxicillin; $A M P$, ampicillin; $A P$, alkaline phosphatase; $B R E T$, bioluminescence resonance energy transfer; $B S A$, bovine serum albumin; $C A P$, chloramphenicol; $C L$, chemiluminescence; $C L E I A$, chemiluminescent enzyme immunoassay; $C R$, cross-reactivity; $D R$, dynamic range; $E N R$, enrofloxacin; $F a b$, antigen-binding fragment; $F Q$, fluoroquinolone; $G E N T$, gentamicin; $H R P$, horseradish peroxidase; icELISA, indirect competitive ELISA; $L O D$, limit of detection; $m A b$, monoclonal antibody; NOR, norfloxacin; $n . d$., not determined; $O V A$, ovalbumin; $P C s$, penicillins; $Q D$, quantum dot; $R L u c$, Renilla luciferase; Sara, sarafloxacin; $s c F v$, single-chain variable fragment; $V_{H}, V_{L}$, heavy and light variable regions of $\mathrm{Ab}$

world have established a legislative framework to control these chemicals in foodstuffs [132], and sensitive analytical methods are needed to control their presence in both raw materials and processed foods. The number of papers dealing with the analysis of pesticides in food is extensive, and immunochemical techniques have been regularly applied to their control during decades [133-135].

As is the case of mycotoxins and antibiotics, pesticides are also haptens with low molecular weights; and thus, the use of the recombinant antibody technology would also be beneficial for the development of advanced immunoassay methodologies. Selected examples of the application of recombinant antibodies in this area are discussed below, and Table 5 collects the characteristics of selected rAb-based immunoassays reported for the analysis of pesticides in food since 2015.

Carbamates and organophosphorus (OP) pesticides are most widely applied in agro-industrial processes, and many analytical methods have been reported for their analysis. Immunoassay applications for the analysis of these pesticides in food are based, in many cases, on the application of 
Fig. 3 Schematic of QD-BRET based on scFv-Rluc and QDs for the detection of several FQs. A QD-NOR binds to scFv-Rluc in the absence of the antibiotic and the energy released from the substrate is transferred to the QDs $(620 \mathrm{~nm})$ via BRET. B In the presence of the target antibiotic, scFv-Rluc binds to the FQ increasing the distance between the Rluc and QDs; thus, no energy transfer is observed. Reprinted (adapted) with permission from [123]. Copyright (2016) American Chemical Society
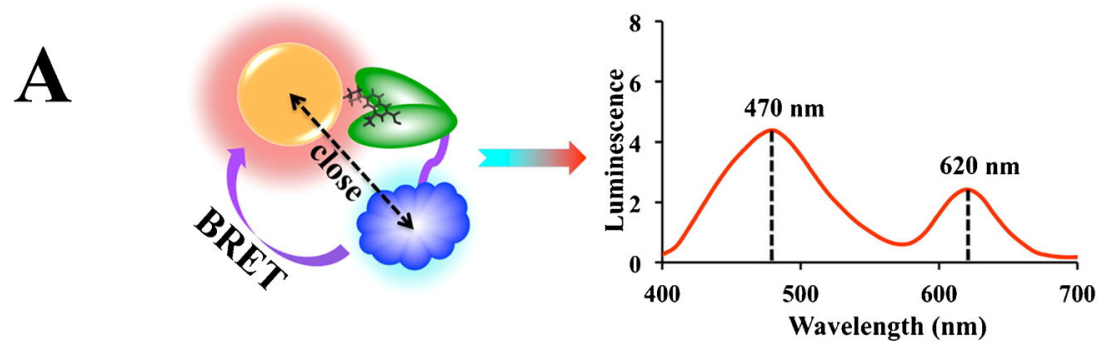

B
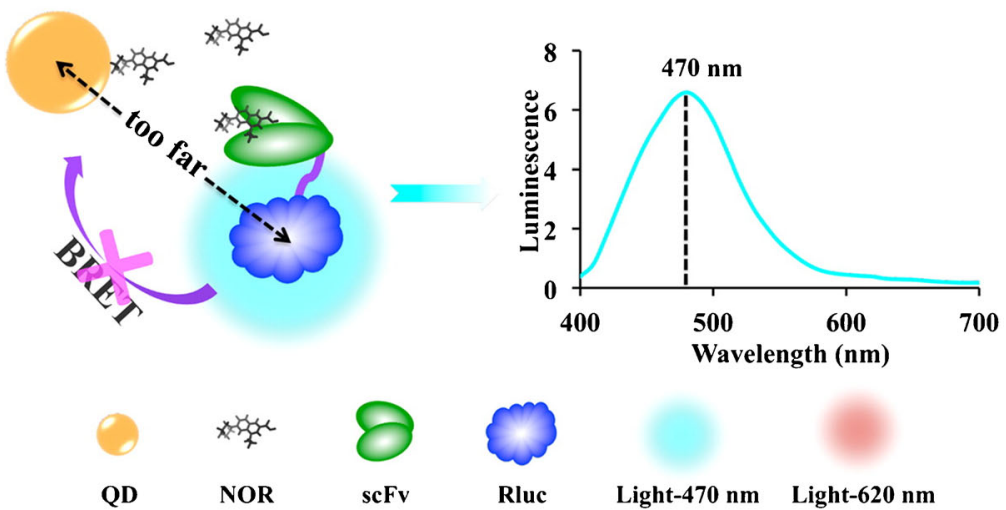

Light-470 nm Light-620 nm engineered antibodies generated in vitro using phage display libraries. As shown in Table 5, these libraries generally consist of antibodies from a variety of species (chicken, mice, camelid, and alpaca) from different origins (naïve or immunized) and in different formats, in terms of fragment antibody type $\left(\mathrm{V}_{\mathrm{H}}, \mathrm{V}_{\mathrm{HH}}, \mathrm{scFv}, \mathrm{Fab}\right)$. As discussed previously, it is usually challenging to isolate a highly sensitive target-specific $\mathrm{rAb}$ from a naïve phage display library [106]; therefore, some authors have reported the construction of personalized immunized antibody libraries that allow the isolation of antibodies with high affinity and selectivity for the target pesticide [137, 139, 142].

Several immunized chicken and alpaca phage display antibody libraries have been prepared for the detection of carbaryl in foodstuff. For example, two scFv mutants (X1 and X2) against the insecticide were generated from a chicken immunized with carbaryl-related hapten conjugated to keyhole limpet hemocya$\operatorname{nin}(\mathrm{KLH})$ [137]. The scFv antibodies were genetically fused to AP to develop a one-step ELISA method. The binding affinity of scFv-AP to carbaryl was evaluated by icELISA and compared with the native scFv. The assays showed 2 or 3 times better sensitivities than the classical ELISA based on the hapten-BSA conjugates and colorimetric detection. The authors suggested that the improvement in sensitivity could be related to the prevention of aggregates and dimerizations that usually happens during the expression of $\mathrm{scFv}[145,146]$. In fact, the $\mathrm{scFv}$ AP (X2) fragment showed a better sensitivity to carbaryl than parental scFv featuring an LOD of $1.6 \mathrm{ng} / \mathrm{mL}\left(\mathrm{IC}_{50} 15 \mathrm{ng} / \mathrm{mL}\right)$. No cross-reactivity was observed with other pesticides, and the assay was successfully applied to the analysis of fruit and soil samples with recoveries in the range of 90-114\%, with CVs of 6-11\%. The same authors [140] applied also $\mathrm{V}_{\mathrm{HH}}$ antibodies isolated from an immunized alpaca library to the detection of carbaryl in cereal samples. The assay was linear in the range of $0.8-38 \mathrm{ng} / \mathrm{mL}$ with an $\mathrm{IC}_{50}$ of $5.4 \mathrm{ng} / \mathrm{mL}$ and a LOD of $0.3 \mathrm{ng} /$ $\mathrm{mL}$. Thus, the sensitivity was better than with the scFv-AP approach, although worse than other methods using conventional antibodies. The authors claimed that the $\mathrm{V}_{\mathrm{HH}}$ would be more suitable for binding to larger molecules than to small ones because the CDR3 moiety of heavy-chain antibody domain fragments is long and fits better in the concave binding sites and cryptic pockets of protein antigens [147]. The selectivity for other tested carbamates, such as methylcarb, pirimicarb, propoxur, or carbosulfan, was lower than $8 \%$. Recoveries of carbaryl and reproducibility of the method when analyzing spiked rice, maize, and wheat samples were satisfactory (recovery $81-$ $113 \%$, CV 2.9-9.7\%).

In a similar approach, but using a $\mathrm{V}_{\mathrm{HH}^{-}} \mathrm{AP}$ fusion, Zhang et al. [142] developed a one-step ELISA to detect parathion in cabbage, cucumber, and lettuce samples. The authors suggested that the simplicity of the assay favored the enhanced sensitivity compared with a direct competitive ELISA or an icELISA. In this case, the use of a fluorogenic substrate resulted in 3-4-fold improvement in the sensitivity $\left(\mathrm{IC}_{50} 1.6 \mathrm{ng} / \mathrm{mL}\right.$ and LOD $0.2 \mathrm{ng} / \mathrm{mL}$ ) achieved with the assay, showing the importance of selecting the appropriate detection method [148].

Ideally, recombinant antibody fragments might exhibit high affinity, simple heterogeneous expression in bacteria, 


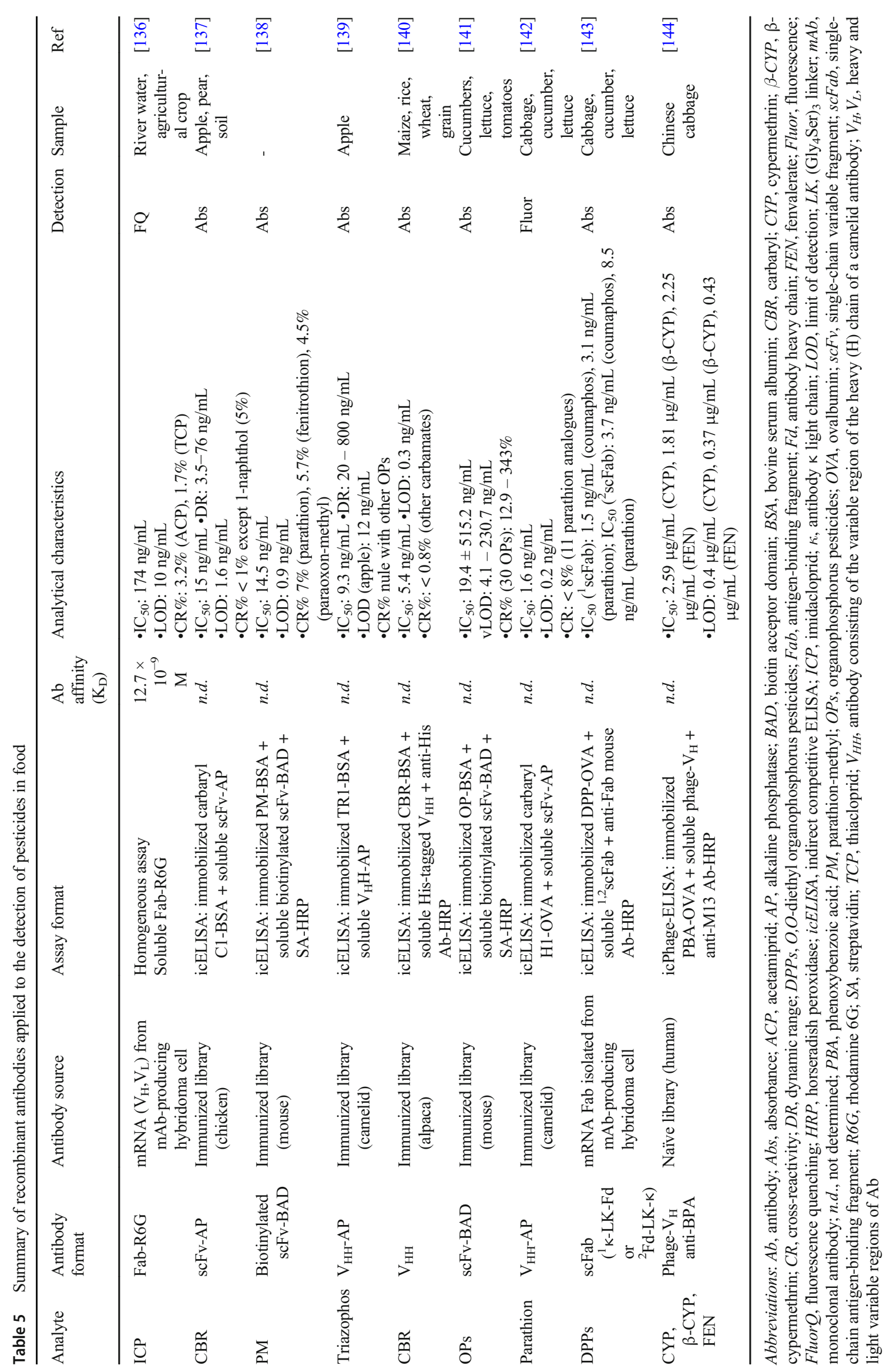


and long-term stability. However, the widely used scFv and Fab forms do not meet all these requirements, hindering their broad commercialization as immunoanalytical regents. In this regard, Wang et al. [29] proposed a novel rAb format, a single-chain Fab fragment (scFab; Fig. 1c), obtained by genetic manipulation of the target $\mathrm{Fab}$ gene to analyze $O, O$ diethyl organophosphorus pesticides (DPPs) in food samples. The advantages of scFab are well described [149], highlighting the combined stability and assay performance of Fab fragments with the high level of bacterial expression as a soluble antibody, similar to scFvs. In the study, the authors tested the impact of two different orientations for the $\mathrm{Fd}$ and $\mathrm{\kappa}$ fragments to form scFab anti-DPPs with improved production and functionality. The best scFab format was selected by evaluating the expression levels in E. coli and its analytical characteristics (sensitivity and selectivity) compared to the respective $\mathrm{scFv}$ and Fab analogues. Better sensitivities were achieved using the $\mathrm{K}$-linker-Fd scFab and the original $\mathrm{Fab}$ in comparison with the $\mathrm{scFv}$ fragment $\left(\mathrm{IC}_{50}\right.$ for DPP parathion using Fab forms was $3.1 \mathrm{ng} / \mathrm{mL}$ vs $6.2 \mathrm{ng} / \mathrm{mL}$ for scFv). In addition, the expression extract scFab showed a similar activity than the $\mathrm{scFv}$ variant and higher than the Fab fragment, confirming the drawbacks of soluble Fab production in bacteria. Finally, the optimal recombinant scFab was used for the analysis of DPPsspiked cabbage, cucumber, and lettuce samples by icELISA. The results revealed good sensitivity and reproducibility for the target pesticides with recoveries in the range of $70-121 \%$ and CVs of 4-20\%.

As reported previously for other small molecule targets, immunosensing approaches using rAbs to analyze pesticides are also scarce. An interesting approach was reported by Zhao et al. using a quenchbody (Q-body) for the analysis of imidacloprid (ICP) [136]. Q-bodies were made by conjugating fluorescent probes to Fab fragments, and they allowed the fast and sensitive analysis of the pesticide without the need for additional reagents [150]. The measuring principle was based on the antigen-dependent removal of the quenching effect on rhodamine $6 \mathrm{G}$ of the tryptophan residues in the variable region of the Fab by via photoinduced electron transfer (PET). The homogenous assay exhibited high sensitivity to imidacloprid $(10 \mathrm{ng} / \mathrm{mL})$ and low cross-reactivity with other insecticides, such as acetamiprid (CR\% 3.2\%) and thiacloprid (CR\% 1.7\%).

\section{Future perspectives}

The use of antibodies as selective recognition elements is essential for basic research, diagnostics, and therapeutics applications. According to a recent report published by MarketsandMarkets ${ }^{\mathrm{TM}}$, the global market is projected to reach USD 652 million by 2026 from USD 393 million in 2021, at a compound annual growth rate (CAGR) of $10.6 \%$ during the forecast period [151]. The report includes monoclonal, polyclonal, and recombinant antibodies, and rAbs are expected to achieve the highest growth rate during the analyzed period.

Moreover, the COVID-19 pandemic has had an enormous and positive impact on the global custom antibody market. The production of recombinant SARS-CoV-2 binders in just a few weeks from naïve antibody libraries by a host of academic and industrial groups have demonstrated the potential of this technology to develop treatments, vaccines, and diagnostic kits [9]. New funding opportunities in this area are expected to be an incentive for the production and application of non-animal-derived products.

As discussed previously, the production of recombinant antibodies in vitro is especially based on the application of phage and yeast display techniques. Phage display continues to be the most common technique and it allows the isolation of recombinant antibodies from different species (human, camel, llama, shark, macaque, rabbit, or mice). Depending on the source, antibody libraries can be classified either in naïve, immunized, semisynthetic, or synthetic repertoires [152]. The construction of immunized libraries requires the availability of patients or immunized/infected animals to isolate affinity matured antibodies, and a new library must be produced for every target of interest. Such libraries are widely applied not only in medical research, but also for the isolation of highly sensitive antibodies for food analysis [75, 101-103]. On the other hand, the use of naïve libraries allows circumventing the ethical problems and limitations associated to the use of animal-derived antibodies. Unlike immunized libraries, they can be applied for the generation of antibodies against a wide variety of compounds including non-immunogenic, pathogenic, conserved, or self-targets, which is of interest in food analysis. Nowadays, the libraries are rather large (approximately ten billion antibodies) in comparison to the initial developments, which increases the possibilities of isolating high-affinity antibodies if good selection strategies are applied. Semi-synthetic libraries include a combination of CDRs from natural sources and in silico design of defined parts, whereas synthetic libraries are completely based on in silico design and gene synthesis resulting in a well-defined and controlled composition of the CDRs. The application of in silico techniques for the design of recognition molecules has been identified as an exciting area of research for the next decade [153].

At present, a major bottleneck that requires attention is the characterization of the isolated antibodies (e.g., western blots, immunofluorescence, immunohistochemistry, flow cytometry) prior to commercialization [11]. Companies should not only produce the antibodies but also characterize them and guarantee batch-to-batch fidelity. In fact, there is an increasing concern about reproducibility issues due to the application of poorly validated animal-derived antibodies with the corresponding waste of time, money, and human resources. 
Recombinant antibodies are versatile and their selectivity can be finely tuned by mutation strategies and controlling the selection criteria during panning. More importantly, the reproducibility between batches, specificity, and long-term supply of recombinant antibodies in combination with other advantages, such as the rapid generation or wider range of target compounds, may represent an economic advantage for companies using this technology and provide higher quality antibodies.

The application of nanobodies for analysis purposes is especially attractive as they can stand harsh measuring conditions, such as extreme temperatures or, for example, the presence of organic solvents that would denature classical antibodies and are usually applied for the extraction of food contaminants. On the other hand, their small size allows the preparation of high-density sensing layers with low non-specific adsorption of interfering species with the corresponding improvement in the assay sensitivity. Moreover, nanobodies as well as other recombinant antibody fragments can be engineered to fit the needs of the final application, for example by a genetic fusion to affinity tags for purification purposes or for their oriented immobilization on sensing platforms [154]. These characteristics together with the robustness, relatively low production costs, and large-scale production make nanobodies especially attractive for the development of biosensing devices and diagnostics kits. They can also broaden the application of affinity reagents for in vivo diagnostics due to their ideal biodistribution properties and fast elimination via kidneys [154].

According to the EURL ECVAM, broad application of non-animal-derived antibodies has been hindered by several challenges; first of all, there is a big tendency to avoid the use of new methods; second, recent advances in the non-animalderived technology are unknown in many areas of biological research; third, legal and economic constraints have prevented some companies from entering this market; and, fourth, there is limited access to non-animal-derived antibody sources both from academic and commercial sources [3]. In any case, the development of non-animal-derived antibody techniques has increased notably in the last decade and companies have started to include in vitro generated antibodies in their catalogues. However, although some companies have already included a good number of recombinant antibodies in their catalogues for therapeuthic applications [9], at present the available technology and infrastructure is not developed enough for upscaling and the prices for custom-made services are expensive [155]. In addition, only a few companies, such as Creative-Biolabs [156] that include recombinant antibodies for OTA and $\mathrm{ZON}$ in their portfolio, focus on food applications.

Nowadays, there is an opportunity for companies and users operating under the EU regulation to replace animal-derived antibodies by the non-animal antibody technology that should be exploited. A broader question, however, is whether nonanimal-derived antibodies are capable of replacing monoclonal and polyclonal antibodies that have ruled the field for decades. In recent years, there is a continuous trend to try to replace animal-derived antibodies for recombinant constructs from naïve or degenerated libraries and the use of synthetic constructs, and the literature revised in this review indeed shows the advent of recombinant alternatives for food analysis. While at present complete replacement of monoclonal and polyclonal antibodies by non-animal-derived ones is unlikely, recombinant antibodies should be considered a valuable complementary or even alternative option, especially in certain applications where their adaptability is a true advantage.

\section{Conclusions}

Antibody-based technologies have revolutionized the rapid detection of many common contaminants in foodstuffs, including toxins, pesticides, antibiotics, and foodborne pathogens. The limitations associated with conventionally used monoclonal and polyclonal antibodies, as well as concerns of unnecessary use of animals for antibody production, have also spurred efforts to explore recombinant antibodies for food safety applications. Several examples presented in this review show the potential of recombinant antibodies for highly sensitive and specific detection of food contaminants. While not all applications with recombinant antibodies are capable of competing with monoclonal antibodies in terms of sensitivity, they might bring other advantages to the system, including small size, stability in harsh conditions, flexibility, and potential to genetically engineer the binder, as well as simple and low-cost animal-free production. Yet, in spite of the benefits of recombinant antibodies, their application in the field of immunoassays and especially biosensors for food analysis is still not widely exploited. However, monoclonal and polyclonal antibodies have some 40 years of head start, and it remains to be seen how far recombinant antibodies can go once they become more widely available. Some commercial providers have already included a number of recombinant antibodies in their selection, which can be expected to boost their widespread use. Moreover, academic consortia bringing together experts from different fields can serve as an important manner to promote the use of recombinant antibodies and establish new innovative antibody-based technologies for safer food.

Author contribution The manuscript was written through contributions from all the authors.

Funding This work was supported by the Spanish Ministry of Economy and Competitiveness (Grant RTI2018-096410-B-C21) and by PI17CIII/ 
00045 and PI20CIII/00019 grants, partially supported by FEDER funds from the AES-ISCIII program to R. B.

Data availability Not applicable.

Code availability Not applicable.

\section{Declarations}

Conflict of interest The authors declare no conflict of interest.

M. C. Moreno-Bondi is Editor of Analytical and Bioanalytical Chemistry and was not involved in peer reviewing of this manuscript

\section{References}

1. Borrebaeck CA. Antibodies in diagnostics - from immunoassays to protein chips. Immunol Today. 2000. https://doi.org/10.1016/ s0167-5699(00)01683-2.

2. Howard GC, Kaser MR. Making and using antibodies: a practical handbook. 2nd ed. Boca Raton: CRC Press; 2014.

3. Barroso J, Halder M, Whelan M. EURL ECVAM Recommendation on non-animal-derived antibodies. EUR 30185 EN, Publications Office of the European Union, Luxembourg, 2020. https://doi.org/10.2760/091625

4. Uhlen M, Bandrowski A, Carr S, Edwards A, Ellenberg J, Lundberg E, et al. A proposal for validation of antibodies. Nat Methods. 2016. https://doi.org/10.1038/nmeth.3995.

5. Barderas R, Benito-Peña E. The 2018 Nobel Prize in chemistry: phage display of peptides and antibodies. Anal Bioanal Chem. 2019. https://doi.org/10.1007/s00216-019-01714-4.

6. Holliger P, Hudson PJ. Engineered antibody fragments and the rise of single domains. Nat Biotechnol. 2005. https://doi.org/10. 1038/nbt1142.

7. Alfaleh MA, Alsaab HO, Mahmoud AB, Alkayyal AA, Jones ML, Mahler SM, et al. Phage display derived monoclonal antibodies: from bench to bedside. Front Immunol. 2005. https://doi. org/10.3389/fimmu.2020.01986.

8. Directive 2010/63/EU of the European Parliament and of the Council of 22 September 2010 on the protection of animals used for scientific purposes Off J European Union. 2005; L129/16.

9. Gray A, Bradbury ARM, Knappik A, Plückthun A, Borrebaeck CAK, Dübel S. Animal-free alternatives and the antibody iceberg. Nat Biotechnol. 2020. https://doi.org/10.1038/s41587-020-0687-9.

10. Gray AC, Bradbury ARM, Knappik A, Plückthun A, Borrebaeck CAK, Dübel S. Animal-derived-antibody generation faces strict reform in accordance with European Union policy on animal use. Nat Methods. 2020;1. https://doi.org/10.1038/s41592-020-0906-9.

11. Marx V. Change-makers bring on recombinant antibodies. Nat Methods. 2020. https://doi.org/10.1038/s41592-020-0915-8.

12. Janeway CA, Travers P, Walport M, Shlomchik MJ. Immunobioloogy: the immune system in health and disease. 5th ed. New York: Garland Science; 2001.

13. Vincke C, Muyldermans S. Introduction to heavy chain antibodies and derived nanobodies. In: Saerens D, Muyldermans S, editors. Single domain antibodies. Totowa: Humana Press; 2012. p. 15-26.

14. Padlan EA. Anatomy of the antibody molecule. Mol Immunol. 1994. https://doi.org/10.1016/0161-5890(94)90001-9.

15. Sehnal D, Bittrich S, Deshpande M, Svobodová R, Berka K, Bazgier V, et al. Mol* Viewer: modern web app for 3D visualization and analysis of large biomolecular structures. Nucleic Acids Res. 2021. https://doi.org/10.1093/nar/gkab314.
16. Schroeder HW, Cavacini L. Structure and function of immunoglobulins. J Allergy Clin Immunol. 2010. https://doi.org/10.1016/ j.jaci.2009.09.046.

17. Leenaars M, Hendriksen CFM. Critical steps in the production of polyclonal and monoclonal antibodies: evaluation and recommendations. ILAR J. 2005. https://doi.org/10.1093/ilar.46.3.269.

18. Colwill K, Renewable Protein Binder Working Group, Gräslund S. A roadmap to generate renewable protein binders to the human proteome. Nat Methods. 2011. https://doi.org/10.1038/nmeth. 1607.

19. O'Kennedy R. Rapid antibody-based technologies in food analysis. London: The Royal Society of Chemistry; 2019.

20. Bradbury A, Plückthun A. Reproducibility: standardize antibodies used in research. Nature. 2015. https://doi.org/10.1038/518027a.

21. Köhler G, Milstein C. Continuous cultures of fused cells secreting antibody of predefined specificity. Nature. 1975. https://doi.org/ 10.1038/256495a0.

22. Bradbury ARM, Trinklein ND, Thie H, Wilkinson IC, Tandon $\mathrm{AK}$, Anderson S, et al. When monoclonal antibodies are not monospecific: hybridomas frequently express additional functional variable regions. MAbs. 2018. https://doi.org/10.1080/ 19420862.2018.1445456.

23. Tomszak F, Weber S, Zantow J, Schirrmann T, Hust M, Frenzel A. Selection of recombinant human antibodies. Adv Exp Med Biol. 2016. https://doi.org/10.1007/978-3-319-32805-8_3.

24. Frenzel A, Hust M, Schirrmann T. Expression of recombinant antibodies. Front Immunol. 2013. https://doi.org/10.3389/fimmu. 2013.00217.

25. Charlton KA. Expression and isolation of recombinant antibody fragments in E. coli. Methods Mol Biol. 2004. https://doi.org/10. 1385/1-59259-666-5:245.

26. Sharma S, Byrne H, O'Kennedy RJ. Antibodies and antibodyderived analytical biosensors. Essays Biochem. 2016. https://doi. org/10.1042/EBC20150002.

27. Hu Z-Q, Li H-P, Wu P, Li Y-B, Zhou Z-Q, Zhang J-B, et al. An affinity improved single-chain antibody from phage display of a library derived from monoclonal antibodies detects fumonisins by immunoassay. Anal Chim Acta. 2015. https://doi.org/10.1016/j. aca.2015.02.014

28. Li X, Li P, Lei J, Zhang Q, Zhang W, Li C. A simple strategy to obtain ultra-sensitive single-chain fragment variable antibodies for aflatoxin detection. RSC Adv. 2013. https://doi.org/10.1039/ c3ra42706d.

29. Miersch S, Li Z, Hanna R, McLaughlin ME, Hornsby M, Matsuguchi T, et al. Scalable high throughput selection from phage-displayed synthetic antibody libraries. J Vis Exp. 2015. https://doi.org/10.3791/51492.

30. Barderas R, Desmet J, Timmerman P, Meloen R, Casal JI. Affinity maturation of antibodies assisted by in silico modeling. Proc Natl Acad Sci U S A. 2008. https://doi.org/10.1073/pnas.0801221105.

31. Barderas R, Desmet J, Alard P, Casal JI. Affinity maturation by semi-rational approaches. Methods Mol Biol. 2012. https://doi. org/10.1007/978-1-61779-974-7 27.

32. Smith GP. Filamentous fusion phage: novel expression vectors that display cloned antigens on the virion surface. Science. 1985. https://doi.org/10.1126/science.4001944.

33. Bradbury ARM, Sidhu S, Dübel S, McCafferty J. Beyond natural antibodies: the power of in vitro display technologies. Nat Biotechnol. 2011. https://doi.org/10.1038/nbt.1791.

34. Frenzel A, Schirrmann T, Hust M. Phage display-derived human antibodies in clinical development and therapy. mAbs. 2016. https://doi.org/10.1080/19420862.2016.1212149.

35. Peltomaa R, López-Perolio I, Benito-Peña E, Barderas R, MorenoBondi MC. Application of bacteriophages in sensor development. Anal Bioanal Chem. 2016. https://doi.org/10.1007/s00216-0159087-2. 
36. Zeng X, Shen Z, Mernaugh R. Recombinant antibodies and their use in biosensors. Anal Bioanal Chem. 2012. https://doi.org/10. 1007/s00216-011-5569-z.

37. Tschofen M, Knopp D, Hood E, Stöger E. Plant molecular farming: much more than medicines. Annu Rev Anal Chem. 2016. https://doi.org/10.1146/annurev-anchem-071015-041706.

38. Xenaki KT, Oliveira S, van Bergen EN, Henegouwen PMP. Antibody or antibody fragments: implications for molecular imaging and targeted therapy of solid tumors. Front Immunol. 2017. https://doi.org/10.3389/fimmu.2017.01287.

39. Gallo E, Wienbar S, Snyder AC, Vasilev KV, Armitage BA, Jarvik JW. A single-chain-variable-fragment fluorescence biosensor activates fluorogens from dissimilar chemical families. Protein Pept Lett. 2014;21:1289-94.

40. Ahmad ZA, Yeap SK, Ali AM, Ho WY, Alitheen NBM, Hamid M. scFv antibody: principles and clinical application. Clin Dev Immunol. 2012. https://doi.org/10.1155/2012/980250.

41. Kim H-Y, Lee J-H, Kim MJ, Park SC, Choi M, Lee W, et al. Development of a SARS-CoV-2-specific biosensor for antigen detection using scFv-Fc fusion proteins. Biosens Bioelectron. 2021. https://doi.org/10.1016/j.bios.2020.112868.

42. Alexander A, Steinmetz M, Barritault D, Frangione B, Franklin EC, Hood L, et al. Gamma heavy chain disease in man: cDNA sequence supports partial gene deletion model. Proc Natl Acad Sci U S A. 1982. https://doi.org/10.1073/pnas.79.10.3260.

43. Hamers-Casterman C, Atarhouch T, Muyldermans S, Robinson G, Hamers C, Songa EB, et al. Naturally occurring antibodies devoid of light chains. Nature. 1993. https://doi.org/10.1038/ $363446 \mathrm{a} 0$.

44. Flajnik MF, Kasahara M. Origin and evolution of the adaptive immune system: genetic events and selective pressures. Nat Rev Genet. 2010. https://doi.org/10.1038/nrg2703.

45. Greenberg AS, Avila D, Hughes M, Hughes A, McKinney EC, Flajnik MF. A new antigen receptor gene family that undergoes rearrangement and extensive somatic diversification in sharks. Nature. 1995. https://doi.org/10.1038/374168a0.

46. Singh A, Pasha SK, Manickam P, Bhansali S. Single-domain antibody based thermally stable electrochemical immunosensor. Biosens Bioelectron. 2016. https://doi.org/10.1016/j.bios.2016. 04.054 .

47. Ta DT, Guedens W, Vranken T, Vanschoenbeek K, Steen Redeker E, Michiels L, et al. Enhanced biosensor platforms for detecting the atherosclerotic biomarker VCAM1 based on bioconjugation with uniformly oriented VCAM1-targeting nanobodies. Biosensors. 2016. https://doi.org/10.3390/ bios6030034.

48. Gonzalez-Sapienza G, Rossotti MA, Tabares-da RS. Singledomain antibodies as versatile affinity reagents for analytical and diagnostic applications. Front Immunol. 2017. https://doi. org/10.3389/fimmu.2017.00977.

49. Holt LJ, Herring C, Jespers LS, Woolven BP, Tomlinson IM. Domain antibodies: proteins for therapy. Trends Biotechnol. 2003. https://doi.org/10.1016/j.tibtech.2003.08.007.

50. Nilvebrant J, Tessier PM, Sidhu SS. Engineered autonomous human variable domains. Curr Pharm Des. 2016. https://doi.org/10. 2174/1381612822666160921143011.

51. Adams JJ, Nelson B, Sidhu SS. Recombinant genetic libraries and human monoclonal antibodies. Methods Mol Biol. 2014. https:// doi.org/10.1007/978-1-62703-586-6 9.

52. Chen G, Sidhu SS. Design and generation of synthetic antibody libraries for phage display. Methods Mol Biol. 2014. https://doi. org/10.1007/978-1-62703-992-5 8 .

53. He T, Zhu J, Nie Y, Hu R, Wang T, Li P, et al. Nanobody technology for mycotoxin detection: current status and prospects. Toxins. 2018. https://doi.org/10.3390/toxins 10050180 .
54. Murali R, Greene MI. Structure based antibody-like peptidomimetics. Pharmaceuticals. 2012. https://doi.org/10. 3390/ph5020209.

55. Owens B. Faster, deeper, smaller-the rise of antibody-like scaffolds. Nat Biotechnol. 2017. https://doi.org/10.1038/nbt0717-602.

56. Timmerman P, Barderas R, Desmet J, Altschuh D, Shochat S, Hollestelle MJ, et al. A combinatorial approach for the design of complementarity-determining region-derived peptidomimetics with in vitro anti-tumoral activity. J Biol Chem. 2009. https:/ doi.org/10.1074/jbc.M109.041459.

57. McEnaney PJ, Fitzgerald KJ, Zhang AX, Douglass EF, Shan W, Balog A, et al. Chemically synthesized molecules with the targeting and effector functions of antibodies. J Am Chem Soc. 2014. https://doi.org/10.1021/ja509513c.

58. Ligler FS, Gooding JJ. Lighting up biosensors: now and the decade to come. Anal Chem. 2019. https://doi.org/10.1021/acs. analchem.9b00793.

59. Bazin I, Tria SA, Hayat A, Marty J-L. New biorecognition molecules in biosensors for the detection of toxins. Biosens Bioelectron. 2017. https://doi.org/10.1016/j.bios.2016.06.083.

60. Peltomaa R, Benito-Peña E, Moreno-Bondi MC. Bioinspired recognition elements for mycotoxin sensors. Anal Bioanal Chem. 2018. https://doi.org/10.1007/s00216-017-0701-3.

61. Moran K, O'Kennedy R. Mycotoxins: Contamination, control and analyses. In: O'Kennedy R, editor. Food chemistry, function and analysis. Cambridge: Royal Society of Chemistry; 2019. p. 11238.

62. Mycotoxin handbook. In: https://www.ams.usda.gov/sites/ default/files/media/MycotoxinHB.pdf. Accessed 1 June 2021.

63. Shephard GS. Current status of mycotoxin analysis: a critical review. J AOAC Int. 2016. https://doi.org/10.5740/jaoacint.160111

64. Yamabhai M, Rangnoi K, Sompunga P, O'Kennedy R. Novel recombinant antibody and protein-based approaches for analysis of food and feed contaminants with particular relevance to Asia. In: O'Kennedy R, editor. Food chemistry, function and analysis. Cambridge: Royal Society of Chemistry; 2019. p. 195-222.

65. Min W-K, Kim S-G, Seo J-H. Affinity maturation of single-chain variable fragment specific for aflatoxin B1 using yeast surface display. Food Chem. 2015. https://doi.org/10.1016/j.foodchem. 2015.04.117.

66. Phatsaman J, Hongprayoon R, Mahakarnjanagul W. Construction and characterization of single chain variable fragment-alkaline phosphatase for rapid detection of aflatoxin B1 in an ELISAbased assay. J ISSAAS. 2017;23:79-89.

67. Rangnoi K, Choowongkomon K, O'Kennedy R, Rüker F, Yamabhai M. Enhancement and analysis of human antiaflatoxin $\mathrm{B} 1$ (AFB1) scFv antibody-ligand interaction using chain shuffling. J Agric Food Chem. 2018. https://doi.org/10. 1021/acs.jafc.8b01141.

68. Tang X, Li P, Zhang Q, Zhang Z, Zhang W, Jiang J. Timeresolved fluorescence immunochromatographic assay developed using two idiotypic nanobodies for rapid, quantitative, and simultaneous detection of aflatoxin and zearalenone in maize and its products. Anal Chem. 2017. https://doi.org/10.1021/acs. analchem.7b02794.

69. Hu Z-Q, Li H-P, Liu J-L, Xue S, Gong A-D, Zhang J-B, et al. Production of a phage-displayed mouse $\mathrm{ScFv}$ antibody against fumonisin $\mathrm{B} 1$ and molecular docking analysis of their interactions. Biotechnol Bioproc. 2016. https://doi.org/10.1007/s12257-0150495-0.

70. Ren W, Xu Y, Huang Z, Li Y, Tu Z, Zou L, et al. Single-chain variable fragment antibody-based immunochromatographic strip for rapid detection of fumonisin B1 in maize samples. Food Chem. 2020. https://doi.org/10.1016/j.foodchem.2020.126546. 
71. Shu M, Xu Y, Wang D, Liu X, Li Y, He Q, et al. Anti-idiotypic nanobody: a strategy for development of sensitive and green immunoassay for fumonisin B1. Talanta. 2015. https://doi.org/10. 1016/j.talanta.2015.05.010.

72. Shu M, Xu Y, Dong J, Zhong C, Hammock BD, Wang W, et al. Development of a noncompetitive idiometric nanobodies phage immumoassay for the determination of fumonisin B1. Food Agric Immunol. 2019. https://doi.org/10.1080/09540105.2019. 1604637.

73. Ji Y, He Q, Xu Y, Tu Z, Yang H, Qiu Y, et al. Phage displayed anti-idiotypic nanobody mediated immuno-PCR for sensitive and environmentally friendly detection of mycotoxin ochratoxin A. Anal Methods. 2016. https://doi.org/10.1039/C6AY01264G.

74. Tullila A, Nevanen T. Utilization of multi-immunization and multiple selection strategies for isolation of hapten-specific antibodies from recombinant antibody phage display libraries. IJMS. 2017. https://doi.org/10.3390/ijms18061169.

75. Liu X, Xu Y, Wan D, Xiong Y, He Z, Wang X, et al. Development of a nanobody-alkaline phosphatase fusion protein and its application in a highly sensitive direct competitive fluorescence enzyme immunoassay for detection of ochratoxin A in cereal. Anal Chem. 2015. https://doi.org/10.1021/ac504305z.

76. Liu X, Tang Z, Duan Z, He Z, Shu M, Wang X, et al. Nanobodybased enzyme immunoassay for ochratoxin $A$ in cereal with high resistance to matrix interference. Talanta. 2017. https://doi.org/10. 1016/j.talanta.2016.11.039.

77. Sun Z, Duan Z, Liu X, Deng X, Tang Z. Development of a nanobody-based competitive dot ELISA for visual screening of ochratoxin A in cereals. Food Anal Methods. 2017. https://doi. org/10.1007/s12161-017-0915-1.

78. Qiu Y-L, He Q-H, Xu Y, Bhunia AK, Tu Z, Chen B, et al. Deoxynivalenol-mimic nanobody isolated from a naïve phage display nanobody library and its application in immunoassay. Anal Chim Acta. 2015. https://doi.org/10.1016/j.aca.2015.06.033.

79. Qiu Y-L, He Q-H, Xu Y, Wang W, Liu Y-Y. Modification of a deoxynivalenol-antigen-mimicking nanobody to improve immunoassay sensitivity by site-saturation mutagenesis. Anal Bioanal Chem. 2016. https://doi.org/10.1007/s00216-015-9181-5.

80. Xu Y, Xiong L, Li Y, Xiong Y, Tu Z, Fu J, et al. Citrinin detection using phage-displayed anti-idiotypic single-domain antibody for antigen mimicry. Food Chem. 2015. https://doi.org/10.1016/j. foodchem.2015.01.007.

81. Cheng H, Chen Y, Yang Y, Chen X, Guo X, Du A. Characterization of anti-citrinin specific scFvs selected from non-immunized mouse splenocytes by eukaryotic ribosome display. PLoS One. 2015. https://doi.org/10.1371/journal.pone. 0131482.

82. Xu Y, Xiong L, Li Y, Xiong Y, Tu Z, Fu J, et al. Anti-idiotypic nanobody as citrinin mimotope from a naive alpaca heavy chain single domain antibody library. Anal Bioanal Chem. 2015. https:// doi.org/10.1007/s00216-015-8693-3.

83. Wang X, He Q, Xu Y, Liu X, Shu M, Tu Z, et al. Anti-idiotypic VHH phage display-mediated immuno-PCR for ultrasensitive determination of mycotoxin zearalenone in cereals. Talanta. 2016. https://doi.org/10.1016/j.talanta.2015.09.072.

84. Sompunga P, Pruksametanan N, Rangnoi K, Choowongkomon K, Yamabhai M. Generation of human and rabbit recombinant antibodies for the detection of zearalenone by phage display antibody technology. Talanta. 2019. https://doi.org/10.1016/j.talanta.2019. 04.034 .

85. Arola HO, Tullila A, Kiljunen H, Campbell K, Siitari H, Nevanen TK. Specific noncompetitive immunoassay for HT-2 mycotoxin detection. Anal Chem. 2016. https://doi.org/10.1021/acs. analchem.5b04591.
86. Arola H, Tullila A, Nathanail A, Nevanen T. A simple and specific noncompetitive ELISA method for HT-2 toxin detection. Toxins. 2017. https://doi.org/10.3390/toxins9040145.

87. Kudr J, Zhao L, Nguyen EP, Arola H, Nevanen TK, Adam V, et al. Inkjet-printed electrochemically reduced graphene oxide microelectrode as a platform for HT-2 mycotoxin immunoenzymatic biosensing. Biosens Bioelectron. 2020. https://doi.org/10.1016/j. bios.2020.112109.

88. Wang F, Li Z-F, Yang Y-Y, Wan D-B, Vasylieva N, Zhang Y-Q, et al. Chemiluminescent enzyme immunoassay and bioluminescent enzyme immunoassay for tenuazonic acid mycotoxin by exploitation of nanobody and nanobody-nanoluciferase fusion. Anal Chem. 2020. https://doi.org/10.1021/acs.analchem.0c02338.

89. Tittlemier SA, Cramer B, Dall'Asta C, Iha MH, Lattanzio VMT, Maragos C, et al. Developments in mycotoxin analysis: an update for 2018-19. World Mycotoxin J. 2020. https://doi.org/10.3920/ WMJ2019.2535.

90. Sharma A, Khan R, Catanante G, Sherazi TA, Bhand S, Hayat A, et al. Designed strategies for fluorescence-based biosensors for the detection of mycotoxins. Toxins. 2018. https://doi.org/10.3390/ toxins 10050197 .

91. Maragos CM. Production of anti-idiotype antibodies for deoxynivalenol and their evaluation with three immunoassay platforms. Mycotoxin Res. 2014. https://doi.org/10.1007/s12550014-0190-6.

92. Kavanagh O, Elliott CT, Campbell K. Progress in the development of immunoanalytical methods incorporating recombinant antibodies to small molecular weight biotoxins. Anal Bioanal Chem. 2015. https://doi.org/10.1007/s00216-015-8502-z.

93. The burden of food borne diseases in the WHO European region. In: https://www.euro.who.int/ data/assets/pdf file/0005/ 402989/50607-WHO-Food-Safety-publicationV4-Web.pdf. Accessed 1 June 2021.

94. Aiyedun SO, Onarinde BA, Swainson M, Dixon RA. Foodborne outbreaks of microbial infection from fresh produce in Europe and North America: a systematic review of data from this millennium. Int J Food Sci. 2021. https://doi.org/10.1111/ijfs.14884.

95. Franco-Duarte R, Černáková L, Kadam SS, Kaushik K, Salehi B, Bevilacqua A, et al. Advances in chemical and biological methods to identify microorganisms - from past to present. Microorganisms. 2019. https://doi.org/10.3390/ microorganisms 7050130 .

96. Hameed S, Xie L, Ying Y. Conventional and emerging detection techniques for pathogenic bacteria in food science: a review. Trends Food Sci Technol. 2018. https://doi.org/10.1016/j.tifs. 2018.05.020

97. Hussain W, Ullah MW, Farooq U, Aziz A, Wang S. Bacteriophage-based advanced bacterial detection: concept, mechanisms, and applications. Biosens Bioelectron. 2021. https://doi.org/10.1016/j.bios.2021.112973.

98. Li J, Xu Y, Wang X, Li Y, Wang L, Li X. Construction and characterization of a highly reactive chicken-derived single-chain variable fragment (scFv) antibody against Staphylococcus aureus developed with the T7 phage display system. Int Immunopharmacol. 2016. https://doi.org/10.1016/j.intimp.2016. 02.024 .

99. Hu Y, Sun Y, Gu J, Yang F, Wu S, Zhang C, et al. Selection of specific nanobodies to develop an immuno-assay detecting Staphylococcus aureus in milk. Food Chem. 2021. https://doi. org/10.1016/j.foodchem.2021.129481.

100. Tu Z, Chen Q, Li Y, Xiong Y, Xu Y, Hu N, et al. Identification and characterization of species-specific nanobodies for the detection of Listeria monocytogenes in milk. Anal Biochem. 2016. https://doi.org/10.1016/j.ab.2015.09.023.

101. He Y, Ren Y, Guo B, Yang Y, Ji Y, Zhang D, et al. Development of a specific nanobody and its application in rapid and selective 
determination of Salmonella enteritidis in milk. Food Chem. 2020. https://doi.org/10.1016/j.foodchem.2019.125942.

102. Wang T, Li P, Zhang Q, Zhang W, Zhang Z, Wang T, et al. Determination of Aspergillus pathogens in agricultural products by a specific nanobody-polyclonal antibody sandwich ELISA. Sci Rep. 2017. https://doi.org/10.1038/s41598-017-04195-6.

103. Ji Y, Li X, Lu Y, Guo P, Zhang G, Wang Y, et al. Nanobodies based on a sandwich immunoassay for the detection of staphylococcal enterotoxin B free from interference by protein A. J Agric Food Chem. 2020. https://doi.org/10.1021/acs.jafc.0c00422.

104. Sun T, Zhao Z, Liu W, Xu Z, He H, Ning B, et al. Development of sandwich chemiluminescent immunoassay based on an antistaphylococcal enterotoxin B nanobody-alkaline phosphatase fusion protein for detection of staphylococcal enterotoxin B. Anal Chim Acta. 2020. https://doi.org/10.1016/j.aca.2020.01.032.

105. Zhou Q, Li G, Zhang Y, Zhu M, Wan Y, Shen Y. Highly selective and sensitive electrochemical immunoassay of Cry1C using nanobody and $\pi-\pi$ stacked graphene oxide/thionine assembly. Anal Chem. 2016. https://doi.org/10.1021/acs.analchem.6b02945.

106. Xu C, Zhang C, Zhong J, Hu H, Luo S, Liu X, et al. Construction of an immunized rabbit phage display library for selecting high activity against Bacillus thuringiensis Cry $1 \mathrm{~F}$ toxin single-chain antibodies. J Agric Food Chem. 2017. https://doi.org/10.1021/ acs.jafc.7b01985.

107. Qiu Y, Li P, Dong S, Zhang X, Yang Q, Wang Y, et al. Phagemediated competitive chemiluminescent immunoassay for detecting Cry1 $\mathrm{Ab}$ toxin by using an anti-idiotypic camel nanobody. $\mathrm{J}$ Agric Food Chem. 2018. https://doi.org/10.1021/acs.jafc. $7 \mathrm{~b} 04923$.

108. Zhong J, Hu X, Zhang X, Liu Y, Xu C, Zhang C, et al. Broad specificity immunoassay for detection of Bacillus thuringiensis Cry toxins through engineering of a single chain variable fragment with mutagenesis and screening. Int J Biol Macromol. 2018. https://doi.org/10.1016/j.ijbiomac.2017.09.058.

109. Zhang M, Li G, Zhou Q, Pan D, Zhu M, Xiao R, et al. Boosted electrochemical immunosensing of genetically modified crop markers using nanobody and mesoporous carbon. ACS Sens. 2018. https://doi.org/10.1021/acssensors.8b00011.

110. Xu C, Yang Y, Liu L, Li J, Liu X, Zhang X, et al. Microcystin-LR nanobody screening from an alpaca phage display nanobody library and its expression and application. Ecotoxicol Environ Saf. 2018. https://doi.org/10.1016/j.ecoenv.2018.01.003.

111. Pírez-Schirmer M, Rossotti M, Badagian N, Leizagoyen C, Brena BM, González-Sapienza G. Comparison of three antihapten VHH selection strategies for the development of highly sensitive immunoassays for microcystins. Anal Chem. 2017. https://doi.org/10. 1021/acs.analchem.7b01221.

112. Akter S, Vehniäinen M, Spoof L, Nybom S, Meriluoto J, Lamminmäki U. Broad-spectrum noncompetitive immunocomplex immunoassay for cyanobacterial peptide hepatotoxins (microcystins and nodularins). Anal Chem. 2016. https://doi.org/10.1021/acs.analchem.6b02470.

113. Moreira GMSG, Köllner SMS, Helmsing S, Jänsch L, Meier A, Gronow S, et al. Pyruvate dehydrogenase complex - enzyme 2, a new target for Listeria spp. detection identified using combined phage display technologies. Sci Rep. 2020. https://doi.org/10. 1038/s41598-020-72159-4.

114. Yu J, Sun Z, Sun X, Sun X, Wei H, Jia W, et al. Selection and characterization of a Vibrio parahaemolyticus OmpU antibody by phage display. Microb Pathog. 2020. https://doi.org/10.1016/j. micpath.2020.104136.

115. Then C, Bauer-Panskus A. Possible health impacts of Bt toxins and residues from spraying with complementary herbicides in genetically engineered soybeans and risk assessment as performed by the European Food Safety Authority EFSA. Environ Sci Eur. 2017. https://doi.org/10.1186/s12302-016-0099-0.
116. Díez-Quijada L, Puerto M, Gutiérrez-Praena D, Llana-RuizCabello M, Jos A, Cameán AM. Microcystin-RR: occurrence, content in water and food and toxicological studies. A review. Environ Res. 2019. https://doi.org/10.1016/j.envres.2018.07.019.

117. Melnik S, Neumann A-C, Karongo R, Dirndorfer S, Stübler M, Ibl $\mathrm{V}$, et al. Cloning and plant-based production of antibody MC10E7 for a lateral flow immunoassay to detect [4-arginine]microcystin in freshwater. Plant Biotechnol J. 2018. https://doi.org/10.1111/ pbi.12746.

118. Neumann A-C, Melnik S, Niessner R, Stoeger E, Knopp D. Microcystin-LR Enrichment from freshwater by a recombinant plant-derived antibody using sol-gel-glass immunoextraction. Anal Sci. 2019. https://doi.org/10.2116/analsci.18P384.

119. Shriver-Lake LC, Liu JL, Brozozog Lee PA, Goldman ER, Dietrich R, Märtlbauer E, et al. Integrating scFv into xMAP assays for the detection of marine toxins. Toxins. 2016. https://doi.org/ $10.3390 /$ toxins 8110346

120. Cassini A, Högberg LD, Plachouras D, Quattrocchi A, Hoxha A, Simonsen GS, et al. Attributable deaths and disability-adjusted life-years caused by infections with antibiotic-resistant bacteria in the EU and the European Economic Area in 2015: a population-level modelling analysis. Lancet Infect Dis. 2019. https://doi.org/10.1016/S1473-3099(18)30605-4.

121. Spanish national plan for antibiotic resistance 2019-2021. In: https://www.resistenciaantibioticos.es/es/system/files/field/files/ pran_2019-2021_0.pdf?file $=1 \&$ type $=$ node $\&$ id $=497 \&$ force $=0$. Accessed 4 June 2021.

122. Li C, He J, Ren H, Zhang X, Du E, Li X. Preparation of a chicken $\mathrm{scFv}$ to analyze gentamicin residue in animal derived food products. Anal Chem. 2016. https://doi.org/10.1021/acs.analchem. $6 \mathrm{~b} 00426$.

123. Yu X, Wen K, Wang Z, Zhang X, Li C, Zhang S, et al. General bioluminescence resonance energy transfer homogeneous immunoassay for small molecules based on quantum dots. Anal Chem. 2016. https://doi.org/10.1021/acs.analchem.5b03581.

124. He X, Duan CF, Qi YH, Dong J, Wang GN, Zhao GX, et al. Virtual mutation and directional evolution of anti-amoxicillin $\mathrm{scFv}$ antibody for immunoassay of penicillins in milk. Anal Biochem. 2017. https://doi.org/10.1016/j.ab.2016.10.020.

125. Wang JP, Dong J, Duan CF, Zhang HC, He X, Wang GN, et al. Production and directional evolution of anti-sarafloxacin scFv antibody for immunoassay of fluoroquinolones in milk. J Agric Food Chem. 2016. https://doi.org/10.1021/acs.jafc.6b03356.

126. He K, Wei F, Zhang X, Li J, Zhang D, Wei D. Production and characterization of a single-chain Fv antibody-alkaline phosphatase fusion protein specific for ampicillin. Food Agric Immunol. 2019. https://doi.org/10.1080/09540105.2018.1540550.

127. Du X, Zhou X, Li P, Sheng W, Ducancel F, Wang S. Development of an immunoassay for chloramphenicol based on the preparation of a specific single-chain variable fragment antibody. J Agric Food Chem. 2016. https://doi.org/10.1021/acs.jafc. $6 \mathrm{~b} 00639$.

128. Mala J, Puthong S, Maekawa H, Kaneko Y, Palaga T, Komolpis $\mathrm{K}$, et al. Construction and sequencing analysis of scFv antibody fragment derived from monoclonal antibody against norfloxacin (Nor155). J Genet Eng Biotechnol. 2017. https://doi.org/10.1016/ j.jgeb.2017.02.008.

129. Duan L, Pomerantz RJ. Elimination of endogenous aberrant kappa chain transcripts from sp2/0-derived hybridoma cells by specific ribozyme cleavage: utility in genetic therapy of HIV-1 infections. Nucleic Acids Res. 1994. https://doi.org/10.1093/nar/22.24.5433.

130. Ostermeier $\mathrm{C}$, Michel H. Improved cloning of antibody variable regions from hybridomas by an antisense-directed $\mathrm{RNase} \mathrm{H}$ digestion of the P3-X63-Ag8.653 derived pseudogene mRNA. Nucleic Acids Res. 1996. https://doi.org/10.1093/nar/24.10.1979. 
131. Jiang Z, Jiang X, Li C, Xue H, Zhang X. Development of an IgY antibody-based immunoassay for the screening of the CYP2E1 inhibitor/enhancer from herbal medicines. Front Pharmacol. 2016. https://doi.org/10.3389/fphar.2016.00502.

132. European Food Safety Authority (EFSA), Pesticides. https:// www.efsa.europa.eu/en/topics/topic/pesticides. Accessed 3 Jun 2021.

133. Nara S, Malhotra BD. Applications of immuno-electrochemical detection strategies for food analysis. In: O'Kennedy R, editor. Rapid antibody-based technologies in food analysis. London: The Royal Society of Chemistry; 2019. p. 154-74.

134. Pastucha M, Farka Z, Lacina K, Mikušová Z, Skládal P. Magnetic nanoparticles for smart electrochemical immunoassays: a review on recent developments. Microchim Acta. 2019. https://doi.org/ 10.1007/s00604-019-3410-0.

135. Fang L, Liao X, Jia B, Shi L, Kang L, Zhou L, et al. Recent progress in immunosensors for pesticides. Biosens Bioelectron. 2020. https://doi.org/10.1016/j.bios.2020.112255.

136. Zhao S, Dong J, Jeong H-J, Okumura K, Ueda H. Rapid detection of the neonicotinoid insecticide imidacloprid using a quenchbody assay. Anal Bioanal Chem. 2018. https://doi.org/10.1007/s00216018-1074-y.

137. He J, Tao X, Wang K, Ding G, Li J, Li QX, et al. One-step immunoassay for the insecticide carbaryl using a chicken singlechain variable fragment ( $\mathrm{scFv}$ ) fused to alkaline phosphatase. Anal Biochem. 2019. https://doi.org/10.1016/j.ab.2019.02.022.

138. Wang H, Zhao F, Han X, Yang Z. Production and characterization of a biotinylated single-chain variable fragment antibody for detection of parathion-methyl. Protein Expr Purif. 2016. https://doi. org/10.1016/j.pep.2016.05.005.

139. Wang K, Liu Z, Ding G, Li J, Vasylieva N, Li QX, et al. Development of a one-step immunoassay for triazophos using camel single-domain antibody-alkaline phosphatase fusion protein. Anal Bioanal Chem. 2019. https://doi.org/10.1007/s00216018-01563-7.

140. Liu Z, Wang K, Wu S, Wang Z, Ding G, Hao X, et al. Development of an immunoassay for the detection of carbaryl in cereals based on a camelid variable heavy-chain antibody domain. J Sci Food Agric. 2019. https://doi.org/10.1002/jsfa.9672.

141. Zhao F, Tian Y, Wang H, Liu J, Han X, Yang Z. Development of a biotinylated broad-specificity single-chain variable fragment antibody and a sensitive immunoassay for detection of organophosphorus pesticides. Anal Bioanal Chem. 2016. https://doi.org/10. 1007/s00216-016-9760-0.

142. Zhang Y-Q, Xu Z-L, Wang F, Cai J, Dong J-X, Zhang J-R, et al. Isolation of bactrian camel single domain antibody for parathion and development of one-step dc-FEIA method using VHHalkaline phosphatase fusion protein. Anal Chem. 2018. https:// doi.org/10.1021/acs.analchem.8b03509.

143. Rao MF, Li YJ, Dong JX, Wu WJ, Xu ZL, Sun YM, et al. Production and characterization of a single-chain Fab fragment for the detection of pyret. Anal Methods. 2016. https://doi.org/ 10.1039/C6AY00224B.

144. Zhao Y, Liang Y, Liu Y, Zhang X, Hu X, Tu S, et al. Isolation of broad-specificity domain antibody from phage library for development of pyrethroid immunoassay. Anal Biochem. 2016. https:// doi.org/10.1016/j.ab.2016.02.020.

145. Kortt AA, Dolezal O, Power BE, Hudson PJ. Dimeric and trimeric antibodies: high avidity scFvs for cancer targeting. Biomol Eng. 2001. https://doi.org/10.1016/S1389-0344(01)00090-9.

146. Liu JL, Zabetakis D, Lee AB, Goldman ER, Anderson GP. Single domain antibody-alkaline phosphatase fusion proteins for antigen detection - analysis of affinity and thermal stability of single domain antibody. J Immunol Methods. 2013. https://doi.org/10. 1016/j.jim.2013.04.001.

147. Dumoulin M, Last AM, Desmyter A, Decanniere K, Canet D, Larsson G, et al. A camelid antibody fragment inhibits the formation of amyloid fibrils by human lysozyme. Nature. 2003. https:// doi.org/10.1038/nature01870.

148. Zhao D, Li J, Peng C, Zhu S, Sun J, Yang X. Fluorescence immunoassay based on the alkaline phosphatase triggered in situ fluorogenic reaction of o-phenylenediamine and ascorbic acid. Anal Chem. 2019. https://doi.org/10.1021/acs.analchem.8b05203.

149. Hust M, Jostock T, Menzel C, Voedisch B, Mohr A, Brenneis M, et al. Single chain Fab (scFab) fragment. BMC Biotechnol. 2007. https://doi.org/10.1186/1472-6750-7-14.

150. Creative Biolabs. Quenchbody development. https://www. creative-biolabs.com/adc/quenchbody-development.htm. Accessed 4 Jun 2021.

151. Markets and Markets Custom Antibody Market worth $\$ 652$ million by 2026. Exclusive Report by MarketsandMarketsTM. https://www.prnewswire.com/news-releases/custom-antibodymarket-worth-652-million-by-2026\%2D\%2Dexclusive-reportby-marketsandmarkets-301283296.html. Accessed 8 Jun 2021.

152. Kuhn P, Fühner V, Unkauf T, Moreira GMSG, Frenzel A, Miethe $\mathrm{S}$, et al. Recombinant antibodies for diagnostics and therapy against pathogens and toxins generated by phage display. Proteomics Clin Appl. 2016. https://doi.org/10.1002/prca. 201600002.

153. Ligler FS. Perspective on optical biosensors and integrated sensor systems. Anal Chem. 2009. https://doi.org/10.1021/ac8016289.

154. Muyldermans S. A guide to: generation and design of nanobodies. FEBS J. 2021;288:2084-102. https://doi.org/10.1111/febs.15515.

155. EARA/EFPIA response to EURL ECVAM Recommendation on Non-Animal-Derived antibodies. 2020. https://www.efpia.eu/ media/580524/eara-efpia-antibody-report.pdf. Accessed 14 June 2021.

156. https://www.creativebiolabs.net/anti-ochratoxin-a-fab-fragmentclone-1h2-122742.htm. Accessed 3 Aug 2021.

Publisher's note Springer Nature remains neutral with regard to jurisdictional claims in published maps and institutional affiliations. 